\title{
Closing the phosphorus cycle: Multi-criteria techno-economic optimization of phosphorus extraction from wastewater treatment sludge ash
}

\author{
Lorien Luyckx $^{\mathrm{a}, *}$, Sam Geerts ${ }^{\mathrm{b}}$, Jo Van Caneghem ${ }^{\mathrm{a}}$ \\ ${ }^{a}$ Materials Technology TC, KU Leuven, Campus Group T, Andreas Vesaliusstraat 13, box 2600, 3000 Leuven, Belgium \\ ${ }^{\mathrm{b}}$ Aquafin NV, Dijkstraat 8, 2630 Aartselaar, Belgium
}

\section{A R T I C LE INFO}

\section{Article history:}

Received 10 September 2019

Received in revised form 13 November 2019

Accepted 14 November 2019

Available online $\mathrm{xxx}$

Editor: Daniel CW Tsang

\section{Keywords}

Heavy metal co-extraction

Incineration ash

Phosphorus extraction

Recovery

Sludge

\begin{abstract}
A B S T R A C T
The presence of heavy metals in concentrations above legal limit values is one of the main obstacles preventing closure of the phosphorus (P) cycle through directly applying wastewater treatment sludge ash as a fertilizer. Therefore, an alternative procedure is proposed to recover the valuable $\mathrm{P}$ from the sludge ash via wet chemical extraction. This comprehensive study uses several inorganic and organic acids, chelating agents and an alkaline solution to establish optimal and cost-effective conditions for wet P extraction from sludge ash. The optimization takes into account co-extraction of the following heavy metals: $\mathrm{Cd}, \mathrm{Cr}, \mathrm{Cu}, \mathrm{Ni}, \mathrm{Pb}$ and $\mathrm{Zn}$. Design of experiments results show extraction liquid concentration, liquid/solid ratio and contact time all affect $\mathrm{P}$ and heavy metal extraction efficiency, both individually and through interaction. In addition, type of extraction liquid and $\mathrm{pH}$ at the end of the extraction procedure also affect $\mathrm{P}$ and heavy metal extraction efficiency. Combining results of XRD and SEM-EDX analysis with extraction data shows that at a $\mathrm{pH}<2$, both Ca- and Al-phosphates in the ash dissolve easily. However, at slightly higher pH only Ca-phosphates dissolve well and at alkaline pH only Al-phosphates. The best trade-off between high P extraction, low heavy metal co-extraction and low operational costs is obtained with $\mathrm{H}_{2} \mathrm{SO}_{4}(0.5 \mathrm{~N}, 10 \mathrm{ml} / \mathrm{g}, 120 \mathrm{~min})$ and oxalic acid $(0.5 \mathrm{~N}, 12.8 \mathrm{ml} / \mathrm{g}, 120 \mathrm{~min}) . \mathrm{H}_{2} \mathrm{SO}_{4}$ outperforms the other extraction liquids in terms of extraction liquid costs per $\mathrm{kg}$ P extracted, whereas extraction with oxalic acid results in the lowest heavy metal co-extraction, thus reducing the downstream processing costs. None of the extraction liquids considered is appropriate for heavy metal removal prior to $\mathrm{P}$ extraction due to loss of $\mathrm{P}$ and insufficient heavy metal removal.
\end{abstract}

(C) 2018

\section{Introduction}

Phosphorus (P) is an essential micronutrient for all living organisms. Nowadays, P is mostly extracted from phosphate rock, which is a non-renewable resource that contains $6.5-17.9 \%$ P (European Sustainable Phosphorus Platform, 2019). Globally about 270 million tons of phosphate rock were mined in 2018 and used for manufacturing fertilizers, animal feed and detergents (Desmidt et al., 2015; Donatello et al., 2010b; U.S. Geological Survey, 2019). P reserves are becoming scarce and experts estimate that the global phosphate rock reserves will be depleted within 50 to 100 years (Atienza-Martínez et al., 2014; Donatello et al., 2010b; Xu et al., 2012). However, the production peak is expected to occur even before full depletion (Atienza-Martínez et al., 2014; Kootstra et al., 2019). The European Union considers both $\mathrm{P}$ and phosphate rock as one of the 27 critical raw materials because of its strategic importance and the economic dependence on a limited number of non-EU suppliers (mainly

\footnotetext{
* Corresponding author.

E-mail address: lorien.luyckx@kuleuven.be (L. Luyckx)
}

Morocco, China and the United States of America) (Atienza-Martínez et al., 2014; European Commission, 2017; Kootstra et al., 2019). Therefore, to meet future $\mathrm{P}$ demands, it is important to recover $\mathrm{P}$ from alternative sources, which perfectly fits the idea of a circular economy as prioritized by the European Commission in its Circular Economy Action Plan (European Commission, 2019).

Ash, as a by-product of the incineration of $\mathrm{P}$ rich residues such as wastewater treatment (WWT) sludge, animal manure or animal by-products, is a promising alternative for $\mathrm{P}$ recovery because of its high $\mathrm{P}$ and low moisture content (Atienza-Martínez et al., 2014; Billen et al., 2015; Cohen, 2009; Komiyama et al., 2013; Luyckx et al., 2019). WWT sludge ash, for example, contains between 3.5 and $12.0 \% \mathrm{P}$, which is comparable to the $\mathrm{P}$ content in low grade phosphate rock (Donatello et al., 2010b; Fang et al., 2018b; Wang et al., 2018). In 2012, about 9.6 million tons of dry matter (DM) of sewage sludge was produced in Europe, of which about 25\% was incinerated (Atienza-Martínez et al., 2014; Cohen, 2009; Eurostat, 2019). Upon incineration, $\mathrm{P}$ is not transferred to the gas phase but largely concentrates in the ash (Atienza-Martínez et al., 2014; Cohen, 2009; Fang et al., 2018b). However, the high heavy metal concentrations in the sludge ash might constrain its direct application as a P fertilizer 
(Adam et al., 2009; Gorazda et al., 2016; Kootstra et al., 2019). In this case, an alternative way to close the $\mathrm{P}$ cycle is to recover the valuable P from the sludge ash.

Various methods exist to recover P from waste incineration ash. The ones that have been discussed most frequently in literature are wet chemical extraction (e.g., Atienza-Martínez et al., 2014; Biswas et al., 2009; Cohen, 2009; Darwish et al., 2017; Donatello et al., 2010b; Fang et al., 2018a, 2018b; Franz, 2008; Gorazda et al., 2016; Li et al., 2018; Pettersson et al., 2008; Wang et al., 2018; $\mathrm{Xu}$ et al., 2012), thermochemical treatment (e.g., Adam et al., 2009; Havukainen et al., 2016; Mattenberger et al., 2008; Stemann et al., 2015) and electrodialysis (e.g., Ebbers et al., 2015; Ferreira et al., 2005; Guedes et al., 2014). To many experts, wet chemical extraction is the preferred method because of its high efficiency and low costs (Donatello et al., 2010b; Fang et al., 2018b; Wang et al., 2018). Additionally, wet chemical extraction is similar to the method used for extraction of P from phosphate rock (e.g., patent US 8,425,872 B2 from Ecophos (Takhim, 2013), patent US 9,255,006 B2 from Prayon (Hoxha and Fati, 2016) and patent US 1,816,285 A on the nitrophosphate (Odda) process (Johnson, 1931) which is, for example, operated by BASF). However, waste incineration ash is chemically and mineralogically more complex than phosphate rock and it contains relatively high concentrations of heavy metals. Hence, applying the existing acid extraction method for phosphate rock directly to waste incineration ash is likely to yield operational problems and suboptimal extraction efficiencies. This impedes a fast technologically sound and economically viable implementation of $\mathrm{P}$ recovery from waste incineration ash on industrial scale (Atienza-Martínez et al., 2014; Desmidt et al., 2015). Furthermore, heavy metals in waste incineration ash can be co-extracted and co-precipitated with $\mathrm{P}$ from the extract, in this way negatively affecting the end product quality (Darwish et al., 2017; Donatello et al., 2010b; Fang et al., 2018b; Wang et al., 2018). This emphasizes the need for a tailored P extraction and subsequent recovery method.

The most studied variables affecting $\mathrm{P}$ (and heavy metal) extraction are: type of extraction liquid (Atienza-Martínez et al., 2014; Biswas et al., 2009; Fang et al., 2018b; Kootstra et al., 2019; Wang et al., 2018; Xu et al., 2012), extraction liquid concentration (Atienza-Martínez et al., 2014; Biswas et al., 2009; Cohen, 2009; Darwish et al., 2017; Donatello et al., 2010b; Fang et al., 2018b; Franz, 2008; Wang et al., 2018; Xu et al., 2012), contact time (Atienza-Martínez et al., 2014; Biswas et al., 2009; Darwish et al., 2017; Donatello et al., 2010b; Fang et al., 2018b; Franz, 2008; Xu et al., 2012), liquid/solid (L/S) ratio (Atienza-Martínez et al., 2014; Biswas et al., 2009; Darwish et al., 2017; Donatello et al., 2010b; Fang et al., 2018b; Liang et al., 2019; Xu et al., 2012), pH (Cohen, 2009; Fang et al., 2018b; Franz, 2008; Kootstra et al., 2019), extraction temperature (Biswas et al., 2009), ash composition (Donatello et al., 2010b; Liang et al., 2019; Xu et al., 2012), and upstream operational variables that indirectly affect the ash properties (e.g., combustion temperature) (Atienza-Martínez et al., 2014; Gorazda et al., 2016; Liang et al., 2019). In most of the above-mentioned studies, a one-variable-at-a-time (OVAT) approach was used to study the variable's effect on the $\mathrm{P}$ (and heavy metal) extraction efficiency. Only Darwish et al. (2017) used a design of experiments (DOE) setup. DOE has the advantage over OVAT that it limits the number of experiments and yet yields a high amount of information about the effect of the considered variables and their possible interactions. Furthermore, DOE gives a more quantitative indication of the variables with the highest effect on the $\mathrm{P}$ (and heavy metal) extraction efficiency (Telford, 2007). Moreover, most of the above-mentioned studies only rarely consider economic aspects, except for the work of Cohen (2009), Donatello et al. (2010b) and Kootstra et al. (2019). Additionally, most studies only consider a limited set of extraction liquids: i.e., only inorganic extraction liquids (Cohen, 2009; Darwish et al., 2017; Donatello et al., 2010b; Franz, 2008;
Gorazda et al., 2016) or only comparing inorganic and alkaline extraction liquids (Biswas et al., 2009; Wang et al., 2018; Xu et al., 2012). Furthermore, the use of organic acids (Atienza-Martínez et al., 2014; Fang et al., 2018b; Kootstra et al., 2019) and chelating agents (Fang et al., 2018b) is only rarely investigated.

The overall aim of this comprehensive study is to establish optimal and cost-effective conditions for wet P extraction from WWT sludge ash by means of DOE and multi-criteria optimization. Concretely, this study considers the effect of different types of extraction liquids, extraction liquid concentration, L/S ratio and contact time on the $\mathrm{P}$ (and heavy metal) extraction efficiency. Optimal and cost-effective conditions refer to the best possible trade-off between high P extraction, low heavy metal co-extraction and low operational costs.

\section{Materials and methods}

\subsection{Chemical ash characterization}

The WWT sludge ash was sampled at the electrostatic precipitator of the Aquafin sludge incineration plant in Bruges. This installation annually incinerates 27,000 tons DM of mechanically dewatered WWT sludge in a fluidized bed furnace at bed temperatures between 840 and $850{ }^{\circ} \mathrm{C}$ and a residence time of at least two seconds (Umans and Werquin, 2006). Five liter sludge ash was sampled on 16 October 2018. This sample was homogenized by thorough mixing, after which subsamples were taken for the experiments.

The elemental composition of the sludge ash was determined by microwave-assisted digestion using a combination of aqua regia and hydrofluoric acid (HF). The method used in this paper was based on the European standard EN 13656:2002 (European Committee for Standardization, 2002). A well-sealed Teflon vessel with $250 \mathrm{mg}$ of dry sludge ash, $8 \mathrm{ml}$ aqua regia and $4 \mathrm{ml} \mathrm{HF}$ was placed in a microwave oven (CEM Mars 6 iWave) for $20 \mathrm{~min}$ at $200^{\circ} \mathrm{C}$. Next, HF was neutralized by adding about $4 \mathrm{~g}$ boric acid $\left(\mathrm{H}_{3} \mathrm{BO}_{3}\right)$ and $25 \mathrm{ml}$ demineralized water (18.2 M $\Omega . c m$, Millipore Direct-Q $3 \mathrm{UV}$ ) in the Teflon vessel after which it was placed back in the microwave oven for $10 \mathrm{~min}$ at $170{ }^{\circ} \mathrm{C}$. The cooled solutions were transferred to a $100 \mathrm{ml}$ PP volumetric flask and diluted to the mark. This solution was filtered $(0.45 \mu \mathrm{m})$ and analyzed for $\mathrm{Al}, \mathrm{Ba}, \mathrm{Ca}, \mathrm{Cd}$, Co, Cr, Cu, Fe, K, Mg, Mn, Mo, Na, Ni, P, Pb, S, Si, $\mathrm{Sn}, \mathrm{Ti}, \mathrm{V}$ and $\mathrm{Zn}$ by Inductively Coupled Plasma Optical Emission Spectroscopy (ICP-OES) (Varian 720-ES ICP-OES). No glassware was used for digestion and dilution. The digestion was performed in triplicate and average values and standard deviations were determined to assess statistical significance of trends and differences.

To determine the $\mathrm{pH}$ of the sludge ash, a well-sealed $150 \mathrm{ml}$ HDPE bottle containing $10 \mathrm{~g}$ of dry sludge ash and $100 \mathrm{ml}$ demineralized water (18.2 M $2 . \mathrm{cm}$, Millipore Direct-Q $3 \mathrm{UV}$ ) was placed horizontally on a reciprocating shaker (Heidolph Promax 2020) for $24 \mathrm{~h}$ at maximum speed (400 rpm). Next, the $\mathrm{pH}$ of the solution was measured (SenTix 21 electrode). The experiment was performed in triplicate.

To determine the sludge ash mineralogy in the crystalline phase, a sludge ash sample was mechanically grinded in the presence of ethanol and a corundum $\left(\mathrm{Al}_{2} \mathrm{O}_{3}\right)$ internal standard. Next, it was analyzed by $\mathrm{X}$-ray diffraction (XRD) (D8 Bruker) with $\mathrm{Cu} \mathrm{K}_{\alpha}$ radiation and the data obtained was refined based on the Rietveld method.

Scanning electron microscopy energy-dispersive X-ray (SEM-EDX) analysis (Philips SEM XL30 FEG + EDAX EDX detector) was used to determine the elemental distribution of $\mathrm{Al}, \mathrm{Ca}, \mathrm{Fe}, \mathrm{P}$ and $\mathrm{Si}$ in two selected areas of a sludge ash sample. Mappings were performed with the following settings: (1) $20 \mathrm{kV}$, spot 4, magnification 1200, working distance (WD) $10.51 \mathrm{~mm}$, drift correction on, 16 frames; (2) $12 \mathrm{kV}$, spot 5, magnification 2500, WD $10.34 \mathrm{~mm}$, drift correction on, 24 frames. A non-coated dry sludge ash sample was used for mapping 1 , whereas for mapping 2, a dry sludge ash sample was coated with carbon to avoid excessive charging during measurements. $\mathrm{K}, \mathrm{Mg}$, $\mathrm{Na}$ and $\mathrm{S}$ were not or only slightly visible in the mappings and are therefore not discussed in this paper. 


\subsection{Extraction experiments and design of experiments}

Table 1 gives the fourteen different extraction liquids that were selected based on a literature review and own previous experience (Luy-

\section{Table 1}

Classification of the different extraction liquids considered with reference to previous studies that served as a basis for the applied extraction liquid concentrations, L/S ratios and contact times.

\begin{tabular}{|c|c|c|}
\hline Inorganic acids (IA) & $\mathrm{H}_{2} \mathrm{SO}_{4}$ & 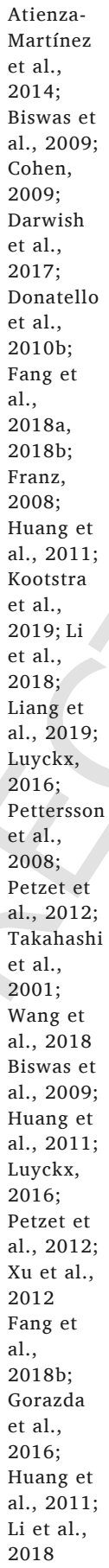 \\
\hline Organic acids (OA) & Acetic acid & $\begin{array}{l}\text { Huang et } \\
\text { al., } 2011 \text {; } \\
\text { Kootstra } \\
\text { et al., } \\
2019\end{array}$ \\
\hline
\end{tabular}

Table 1 (Continued)

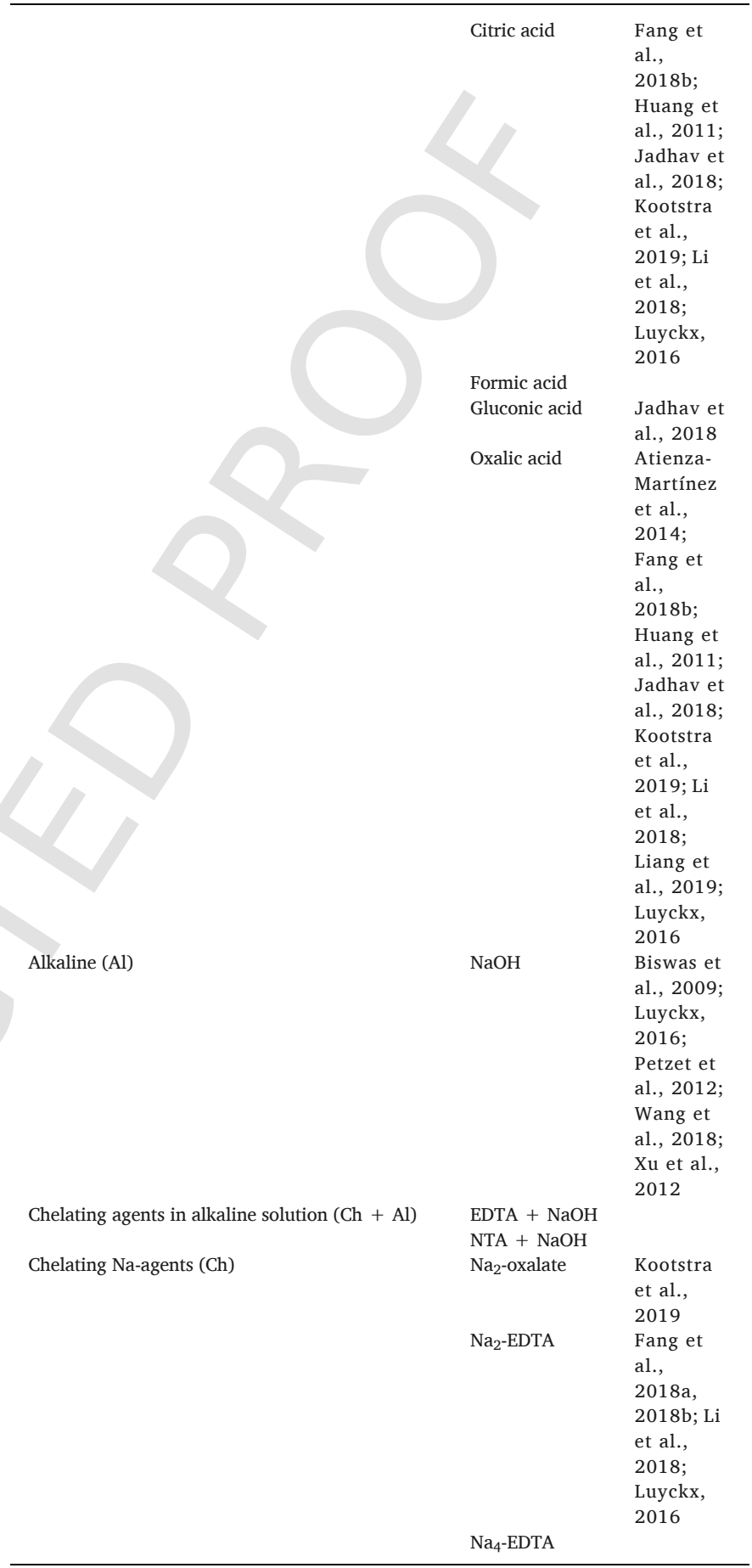

ckx, 2016). The organic acid extraction liquids provided both an acid and complexing extraction environment (Atienza-Martínez et al., 2014; Fang et al., 2018b; Kootstra et al., 2019). Ethylenediaminetetraacetic acid (EDTA) and nitrilotriacetic acid (NTA) were both used in an alkaline solution since their solubility in sodium hydroxide $(\mathrm{NaOH})$ is much higher than in water. Sodium oxalate $\left(\mathrm{Na}_{2}\right.$-oxalate), disodium EDTA $\left(\mathrm{Na}_{2}\right.$-EDTA) and tetrasodium EDTA $\left(\mathrm{Na}_{4}\right.$-EDTA) were included to evaluate the $\mathrm{P}$ extraction efficiency by means of a complexing anion at its intrinsic $\mathrm{pH}$.

For each of the extraction liquids considered, a DOE was set up with three design variables: extraction liquid concentration $\left(\mathrm{X}_{1}\right), \mathrm{L} / \mathrm{S}$ ratio 
$\left(\mathrm{X}_{2}\right)$ and contact time $\left(\mathrm{X}_{3}\right)$. The results of the experiments allowed to determine the effect of these variables and their interactions on the $\mathrm{Al}, \mathrm{Ca}$, $\mathrm{Cd}, \mathrm{Cr}, \mathrm{Cu}, \mathrm{Fe}, \mathrm{K}, \mathrm{Mg}, \mathrm{Ni}, \mathrm{P}, \mathrm{Pb}, \mathrm{Si}$ and $\mathrm{Zn}$ extraction efficiency. For the sake of clarity, the heavy metals $\mathrm{Cd}, \mathrm{Cr}, \mathrm{Cu}, \mathrm{Ni}, \mathrm{Pb}$ and $\mathrm{Zn}$ were selected based on Flemish legislation for the use of waste materials such as WWT sludge ash as a fertilizer (VLAREMA annex 2.3.1.A, 2018). It should be noted that the concentration limit values for heavy metals laid down in the Flemish legislation do not directly apply to the extraction liquid but to the final fertilizer product. However, they serve as a relevant selection base since the heavy metals in the extraction liquid can possibly co-precipitate with $\mathrm{P}$ in the final fertilizer product. Besides the design variables, $\mathrm{pH}$ is also an important variable affecting $\mathrm{P}$ and heavy metal extraction efficiency. However, it was not possible to adapt the $\mathrm{pH}$ in the extraction experiments since it was intrinsically determined by the type and concentration of extraction liquid.

An I-optimality response surface model (Goos and Jones, 2011) with sixteen randomized runs was used, i.e., a face centered central composite design with the central point replicated twice. Accordingly, the extraction liquid concentration, $\mathrm{L} / \mathrm{S}$ ratio and contact time were ranged at three levels $(-1,0$ and 1$)$ for which values were based on a literature review. Second-order polynomial regression models (see Eq. (1), in terms of coded factors) were derived with JMP Pro 14.3.0 software to predict responses. The significance of the independent variables and their interactions was tested by means of analysis of variance (ANOVA) at the 95\% significance level $(\alpha=0.05)$, taking into account the strong heredity principle (Goos and Jones, 2011). The JMP software also calculated $95 \%$ confidence intervals for all polynomial regression models.

$$
\begin{aligned}
Y= & b_{0}+b_{1} X_{1}+b_{2} X_{2}+b_{3} X_{3}+b_{12} X_{1} X_{2}+b_{13} X_{1} X_{3} \\
& +b_{23} X_{2} X_{3}+b_{11} X_{1}^{2}+b_{22} X_{2}^{2}+b_{33} X_{3}^{2}
\end{aligned}
$$

The extraction experiments were carried out at room temperature and all glassware was first rinsed with a $3 \%$ nitric acid $\left(\mathrm{HNO}_{3}\right)$ solution. A well-sealed 50, 100 or $150 \mathrm{ml}$ (depending on L/S ratio) HDPE bottle with $2.5 \mathrm{~g}$ of dry ash and 25,50 or $75 \mathrm{ml}$ extraction liquid with a concentration of $0.1,0.3$ or $0.5 \mathrm{~N}$ was placed horizontally on a reciprocating shaker (Heidolph Promax 2020) for, respectively, 10, 65 or $120 \mathrm{~min}$ at maximum speed $(400 \mathrm{rpm})$. The $\mathrm{pH}$ of the extraction liquid was for each run measured at the start and at the end of the extraction procedure (SenTix 21 electrode). Next, the solutions were filtered $(0.45 \mu \mathrm{m})$ and analyzed for $\mathrm{Al}, \mathrm{Ca}, \mathrm{Cd}, \mathrm{Cr}, \mathrm{Cu}, \mathrm{Fe}, \mathrm{K}, \mathrm{Mg}, \mathrm{Ni}, \mathrm{P}, \mathrm{Pb}, \mathrm{Si}$ and $\mathrm{Zn}$ by ICP-OES (Varian 720-ES ICP-OES). The extraction efficiency was calculated as the amount of element extracted according to Eq. (2):

Extraction efficiency $(\%)$

$=\frac{\text { Element extracted }(\% \text { of DM) }}{\text { Element in ash (\% of DM) }} 100 \%$

\subsection{Multi-criteria optimization}

In order to simultaneously optimize several response variables two multi-criteria technological optimizations were performed: (1) maximize the P extraction efficiency ( $>85 \%$ ) and minimize the heavy metal (Cd, $\mathrm{Cr}, \mathrm{Cu}, \mathrm{Ni}, \mathrm{Pb}$ and $\mathrm{Zn}$ ) extraction efficiency $(<20 \%)$; (2) maximize the heavy metal ( $\mathrm{Cd}, \mathrm{Cr}, \mathrm{Cu}, \mathrm{Ni}, \mathrm{Pb}$ and $\mathrm{Zn}$ ) extraction efficiency ( $>25 \%$ ) and minimize the $\mathrm{P}$ extraction efficiency $(<15 \%)$. No criteria were set for the other elements ( $\mathrm{Al}, \mathrm{Ca}, \mathrm{Fe}, \mathrm{K}, \mathrm{Mg}$ and $\mathrm{Si}$ ). The first optimization yields the optimal $\mathrm{P}$ extraction conditions, whereas the second optimization yields the optimal pre-treatment extraction conditions to remove as many heavy metals as possible before subsequent $\mathrm{P}$ extraction. The desired minimum and maximum $\mathrm{P}$ extraction efficiencies were based on existing P recovery patents (e.g., Patent US 2016/0312333 A1 from Ecophos (Takhim, 2016)) and on the new German sewage sludge ordinance (AbfKlärV) which requires a minimum recovery of
$80 \%$ of total P from WWT sludge ash (The Water Research Foundation, 2019).

For the first multi-criteria optimization, a techno-economic optimization was also performed by adding two economic efficiency response variables: EE1, corresponding to the amount of $\mathrm{P}$ extracted per liter extraction liquid and per day (kg P extracted/1-day), and EE2, corresponding to the extraction liquid costs per $\mathrm{kg} P$ extracted ( $€ / \mathrm{kg} P$ extracted). The only direct costs used in the calculations are the extraction liquid costs. Yet, these economic efficiencies are indirectly also linked to the equipment and energy costs. Firstly, L/S ratio is related to the equipment costs since a higher $\mathrm{L} / \mathrm{S}$ ratio requires a bigger $\mathrm{P}$ extraction reactor to process a certain amount of ash. Secondly, contact time is related to the energy costs since a longer contact time results in a higher energy consumption to process a certain volume of extraction liquid. Both L/S ratio and contact time were used to calculate EE1 and hence both had to be as low as possible to obtain a high amount of $\mathrm{P}$ extracted per liter extraction liquid and per day. This techno-economic optimization was only performed for sulfuric acid $\left(\mathrm{H}_{2} \mathrm{SO}_{4}\right)$, hydrochloric acid $(\mathrm{HCl}), \mathrm{HNO}_{3}$, citric acid, oxalic acid and $\mathrm{NaOH}$, that had the highest $\mathrm{P}$ extraction efficiency according to the multi-criteria technological optimization as well as a relatively good cost-efficiency. Current market prices for these extraction liquids were estimated at $205 € /$ ton for $98 \% \mathrm{H}_{2} \mathrm{SO}_{4}, 220 € /$ ton for $36 \% \mathrm{HCl}, 300 € /$ ton for $68 \% \mathrm{HNO}_{3}, 580 € /$ ton for citric acid anhydrous, $740 € /$ ton for oxalic acid anhydrous and $360 € /$ ton for $\mathrm{NaOH}$ pearls (prices on 9 May 2019, all selected from the same supplier as prices vary considerably between different suppliers) (Chembid, n.d.).

The JMP desirability profiling method was used for the multi-criteria optimizations. For this, a desirability function was specified for each response variable $(\mathrm{P}, \mathrm{Cd}, \mathrm{Cr}, \mathrm{Cu}, \mathrm{Ni}, \mathrm{Pb}, \mathrm{Zn}, \mathrm{EE} 1$ and $\mathrm{EE} 2)$. In this regard, the response variable was transformed to a scale of 0 to 1 , where a value of 1 represented the most desirable value (Obermiller, n.d.). Each desirability function had a specific shape: for the first multi-criteria optimization, the desirability of $\mathrm{P}$ extraction was set at 0.9819 for $100 \%$ extraction efficiency, 0.5 for $92.5 \%$ extraction efficiency and 0.066 for $85 \%$ extraction efficiency. The desirability of heavy metal extraction was set at 0.9819 for $0 \%$ extraction efficiency, 0.25 for $20 \%$ extraction efficiency and 0.066 for $100 \%$ extraction efficiency. The desirability of EE1 was set at $0.9819,0.5$ and 0.066 for the highest, average and lowest possible amount of $\mathrm{P}$ extracted per liter and per day for each specific extraction liquid. The desirability of EE2 was set at $0.9819,0.5$ and 0.066 for the lowest, average and highest possible extraction liquid costs per $\mathrm{kg} P$ extracted for each specific extraction liquid. For the second multi-criteria optimization, the desirability of $\mathrm{P}$ extraction was set at 0.9819 for $0 \%$ extraction efficiency, 0.5 for $7.5 \%$ extraction efficiency and 0.066 for $15 \%$ extraction efficiency. The desirability of heavy metal extraction was set at 0.9819 for $100 \%$ extraction efficiency, 0.5 for $50 \%$ extraction efficiency and 0.066 for $0 \%$ extraction efficiency. The overall desirability for all response variables was defined as the geometric mean of the desirability functions for the individual response variables (JMP, n.d.; Obermiller, n.d.). This overall desirability function takes into account the weighting factor (WF) of each response variable. It should be noted that lower WF's are assigned to more important response variables and accordingly $\mathrm{P}$ was assigned WF 1. WF's for the heavy metals were assigned based on the Flemish legal concentration limit values for the use of waste materials as a fertilizer (VLAREMA annex 2.3.1.A, 2018). Flemish legislation served as a relevant selection base because the specific limit values for each metal are set up in such a way that there is a good trade-off between adequate protection of the environment (i.e., soil and groundwater) and stimulating the reuse of waste materials as a fertilizer (Broos et al., n.d.). The lower the legal concentration limit value for a metal in VLAREMA annex 2.3.1.A, the higher the potential negative environmental effect and hence the lower the WF assigned in this work: Cd was assigned WF 2 (6 mg/kg DM); Ni WF 3 (100 mg/kg DM); Cr WF 4 (150 mg/kg DM); Pb WF 5 (300 mg/kg DM); Cu WF 6 (800 mg/kg 
DM); Zn WF 7 (1500 mg/kg DM) (VLAREMA annex 2.3.1.A, 2018). Furthermore, EE1 and EE2 for the techno-economic optimization were assigned WF 8.

\section{Results and discussion}

\subsection{Chemical ash characterization}

Table 2 gives the elemental composition of the WWT sludge ash considered. The given heavy metal concentrations in the ash were compared with Flemish legal concentration limit values for the use of waste materials as a fertilizer (VLAREMA annex 2.3.1.A, 2018). Table 2 shows that the sludge ash cannot be applied directly as a fertilizer in Flanders because the $\mathrm{Cd}$ and $\mathrm{Zn}$ concentration exceed the legal limit values. Hence, the valuable $\mathrm{P}$ has to be separated from the heavy metals prior to agricultural application.

XRD analysis (see Table 3) showed that the major minerals present in the crystalline phase of the WWT sludge ash were quartz $\left(\mathrm{SiO}_{2}\right)$, whitlockite $\left(\mathrm{Ca} 9(\mathrm{Mg}, \mathrm{Fe})\left(\mathrm{PO}_{4}\right)_{6}\left(\mathrm{PO}_{3} \mathrm{OH}\right)\right)$ and hematite $\left(\mathrm{Fe}_{2} \mathrm{O}_{3}\right)$. The mineralogy of the heavy metals could not be detected by XRD due to their low concentrations in the sludge ash. Calculations to determine the total amount of $\mathrm{P}$ bound in the crystalline and amorphous phase were based on the total amount of P (7.8\% of DM, see Table 2) and whitlockite (11.5\% of DM, see Table 3) in the sludge ash and on the P content in whitlockite $(20.2 \mathrm{wt} \% \mathrm{P}$, calculated with the molar mass of whitlockite and P). These calculations indicated that only about $30 \%$ of total $\mathrm{P}$ was bound in the crystalline phase as whitlockite, whereas the other $70 \%$ was bound in the amorphous phase.

SEM-EDX analysis (see Fig. 1) showed that the P distribution pattern of the WWT sludge ash overlapped most with the Al pattern, followed by the $\mathrm{Ca}$ and $\mathrm{Fe}$ pattern. However, there was almost no overlap between the $\mathrm{P}$ and Si pattern. Hence, $\mathrm{P}$ is probably bound to $\mathrm{Al}, \mathrm{Ca}$ and $\mathrm{Fe}$ and not to $\mathrm{Si}$, which confirms the results of the XRD analysis, except for Al. It is therefore highly likely that (part of) $\mathrm{P}$ occurring in the amorphous phase is bound as $\mathrm{Al}$-phosphates (e.g., $\mathrm{AlPO}_{4}$ or $\mathrm{Al}\left(\mathrm{PO}_{3}\right)_{3}$ ). Furthermore, the areas indicated in red in Fig. 1 are likely mainly whitlockite, a mineral that was also found in the XRD analysis. This can be deduced from the fact that in these areas the atomic ratio of $\mathrm{Ca} / \mathrm{P}$

Table 2

Average elemental composition $(\mu)$ of the WWT sludge ash \pm standard deviation $(\sigma)(\%$ of $\mathrm{DM}$ or $\mathrm{mg} / \mathrm{kg} \mathrm{DM}$ ) ( $\mathrm{n}=3$; subsamples from the same sample). The elemental composition is compared with Flemish legal concentration limit values for the use of waste materials as a fertilizer (VLAREMA annex 2.3.1.A, 2018).

\begin{tabular}{llll}
\hline & & WWT sludge ash & Flemish limits \\
\hline $\mathrm{Al}$ & $(\%$ of DM) & $5.59 \pm 0.02$ & \\
$\mathrm{Ca}$ & $(\%$ of DM) & $6.13 \pm 0.05$ & \\
$\mathrm{Fe}$ & $(\%$ of DM) & $9.76 \pm 0.07$ & \\
$\mathrm{~K}$ & $(\%$ of DM) & $1.56 \pm 0.01$ & \\
$\mathrm{Mg}$ & $(\%$ of DM) & $1.37 \pm 0.01$ & \\
$\mathrm{Na}$ & $(\%$ of DM) & $0.48 \pm 0.01$ & \\
$\mathrm{P}$ & $(\%$ of DM) & $7.80 \pm 0.04$ & \\
$\mathrm{~S}$ & $(\%$ of DM) & $0.32 \pm 0.01$ & \\
$\mathrm{Si}$ & $(\%$ of DM) & $18.49 \pm 0.85$ & \\
$\mathrm{Ba}$ & $(\mathrm{mg} / \mathrm{kg} \mathrm{DM})$ & $630 \pm 122$ & \\
$\mathrm{Cd}$ & $(\mathrm{mg} / \mathrm{kg} \mathrm{DM})$ & $9.6 \pm 0.1$ & 800 \\
$\mathrm{Co}$ & $(\mathrm{mg} / \mathrm{kg} \mathrm{DM})$ & $19.7 \pm 0.1$ & \\
$\mathrm{Cr}$ & $(\mathrm{mg} / \mathrm{kg} \mathrm{DM})$ & $142 \pm 2$ & \\
$\mathrm{Cu}$ & $(\mathrm{mg} / \mathrm{kg} \mathrm{DM})$ & $753 \pm 13$ & 100 \\
$\mathrm{Mn}$ & $(\mathrm{mg} / \mathrm{kg} \mathrm{DM})$ & $604 \pm 3$ & 300 \\
$\mathrm{Mo}$ & $(\mathrm{mg} / \mathrm{kg} \mathrm{DM})$ & $20.7 \pm 0.3$ & \\
$\mathrm{Ni}$ & $(\mathrm{mg} / \mathrm{kg} \mathrm{DM})$ & $66.9 \pm 0.6$ & \\
$\mathrm{~Pb}$ & $(\mathrm{mg} / \mathrm{kg} \mathrm{DM})$ & $267 \pm 2$ & \\
$\mathrm{Sn}$ & $(\mathrm{mg} / \mathrm{kg} \mathrm{DM})$ & $57.2 \pm 0.4$ & \\
$\mathrm{Ti}$ & $(\mathrm{mg} / \mathrm{kg} \mathrm{DM})$ & $4035 \pm 32$ & \\
$\mathrm{~V}$ & $(\mathrm{mg} / \mathrm{kg} \mathrm{DM})$ & $73.5 \pm 0.4$ & \\
$\mathrm{Zn}$ & $(\mathrm{mg} / \mathrm{kg} \mathrm{DM})$ & $2823 \pm 53$ & \\
\hline & & & \\
\hline
\end{tabular}

Table 3

Mineral composition of the crystalline phase of the WWT sludge ash obtained with XRD (\% of DM).

\begin{tabular}{|c|c|c|c|}
\hline & & & $\begin{array}{l}\text { WWT } \\
\text { Sludge } \\
\text { ash } \\
(\% \text { of } \\
\text { DM) }\end{array}$ \\
\hline \multirow[t]{6}{*}{ Silicates } & Quartz & $\mathrm{SiO}_{2}$ & 25.7 \\
\hline & Cristobalite & $\mathrm{SiO}_{2}$ & 2.0 \\
\hline & Tridymite & $\mathrm{SiO}_{2}$ & 6.2 \\
\hline & Plagioclase & $(\mathrm{Na}, \mathrm{Ca})(\mathrm{Si}, \mathrm{Al})_{4} \mathrm{O}_{8}$ & 4.5 \\
\hline & K-feldspar & $(\mathrm{Na}, \mathrm{K}) \mathrm{Si}_{3} \mathrm{AlO}_{8}$ & 2.3 \\
\hline & 2:1 Al clay & $\mathrm{KAl}_{2}\left(\mathrm{Si}_{3} \mathrm{Al}\right) \mathrm{O}_{10}(\mathrm{OH}, \mathrm{F})_{2}$ & 0.2 \\
\hline \multirow[t]{2}{*}{ Oxides } & Hematite & $\mathrm{Fe}_{2} \mathrm{O}_{3}$ & 8.9 \\
\hline & Magnetite & $\mathrm{Fe}_{3} \mathrm{O}_{4}$ & 2.3 \\
\hline Phosphates & Whitlockite & $\mathrm{Ca}_{9}(\mathrm{Mg}, \mathrm{Fe})\left(\mathrm{PO}_{4}\right)_{6}\left(\mathrm{PO}_{3} \mathrm{OH}\right)$ & 11.5 \\
\hline \multirow[t]{2}{*}{ Sulfates } & Bassanite & $\mathrm{CaSO}_{4 \cdot 1} \cdot 2 \mathrm{H}_{2} \mathrm{O}$ & 0.3 \\
\hline & Anhydrite & $\mathrm{CaSO}_{4}$ & 0.8 \\
\hline Halides & Halite & $\mathrm{NaCl}$ & 0.3 \\
\hline Other/amorphous & & & 34.9 \\
\hline
\end{tabular}

almost corresponds to that of whitlockite (9/7). Indeed, the blue color of $\mathrm{Ca}$ is slightly brighter than the green color of $\mathrm{P}$, which means that $\mathrm{Ca}$ is present in a slightly higher atomic concentration. In contrast, the atomic $\mathrm{Fe} / \mathrm{P}$ ratio in mapping 1 and 2 is relatively high compared to that of whitlockite (1/7). A possible explanation for this is that part of the $\mathrm{Fe}$ in the areas indicated in red is bound as hematite or magnetite $\left(\mathrm{Fe}_{3} \mathrm{O}_{4}\right)$. This is confirmed by calculations based on the XRD analysis indicating that $81 \%$ of total $\mathrm{Fe}$ is bound as hematite or magnetite. Additionally, only $3 \%$ of total $\mathrm{Fe}$ is bound to $\mathrm{P}$ as whitlockite and $16 \%$ of total $\mathrm{Fe}$ is bound in the amorphous phase.

Calculations based on the elemental composition of the WWT sludge ash (see Table 2) and on the $\mathrm{Ca} / \mathrm{P}$ ratio of whitlockite indicated that maximum $42 \%$ of total $\mathrm{P}$ can be bound in this mineral (30\% in the crystalline phase and $12 \%$ in the amorphous phase). Similar calculations indicated that maximum $12 \%$ of total $\mathrm{P}$ in the amorphous phase can be bound as $\mathrm{Mg}$-phosphates (e.g., $\left.\mathrm{Mg}_{3}\left(\mathrm{PO}_{4}\right)_{2}\right)$ and maximum $5 \%$ of total $\mathrm{P}$ as $\mathrm{K}$-phosphates (e.g., $\mathrm{K}_{3} \mathrm{PO}_{4}$ ). Unfortunately, this cannot be supported by the SEM-EDX data because $\mathrm{K}$ and $\mathrm{Mg}$ were hardly visible in the mappings. Furthermore, the large overlap of the $\mathrm{P}$ and $\mathrm{Al}$ distribution pattern in Fig. 1 showed that at least part of the unassigned P (41\% of total P) is bound to Al. Hence, it is likely that P located outside the areas indicated in red in Fig. 1 is primarily bound in Al-phosphates. Overall, it can be concluded that $\mathrm{P}$ in the sludge ash considered mainly occurs as whitlockite and Al-phosphates, but the exact share of total P in these two minerals cannot be determined quantitatively.

\section{2. $P$ extraction}

Fig. 2 gives the P extraction efficiencies from the WWT sludge ash in the sixteen randomized runs for all the extraction liquids considered. Only with $\mathrm{H}_{2} \mathrm{SO}_{4}, \mathrm{HCl}, \mathrm{HNO}_{3}$ and oxalic acid, it was possible to extract $>85 \%$ of total $\mathrm{P}$ from the ash. The highest $\mathrm{P}$ extraction efficiencies obtained were $99 \%$ and $89 \%$ with $\mathrm{HCl}$ and $\mathrm{HNO}_{3}$, respectively $(0.3 \mathrm{~N}$, $30 \mathrm{ml} / \mathrm{g}$ and $120 \mathrm{~min}$ ) and $95 \%$ and $93 \%$ with oxalic acid and $\mathrm{H}_{2} \mathrm{SO}_{4}$, respectively ( $0.5 \mathrm{~N}, 50 \mathrm{ml} / \mathrm{g}$ and $120 \mathrm{~min}$ ) (see Table 4). These extraction efficiencies are in line with previously reported results (see Table 4), considering the slightly different extraction liquid concentration and $\mathrm{L} / \mathrm{S}$ ratio.

In this work, the $\mathrm{P}$ extraction efficiency is in general slightly higher for $\mathrm{HCl}$ than for $\mathrm{H}_{2} \mathrm{SO}_{4}, \mathrm{HNO}_{3}$ and oxalic acid (see Fig. 2). For $\mathrm{H}_{2} \mathrm{SO}_{4}$ and oxalic acid, this can be related to the formation of gypsum $\left(\mathrm{CaSO}_{4}\right)$ and Ca-oxalate during extraction, respectively. The formation of poorly 
(a) Mapping 1
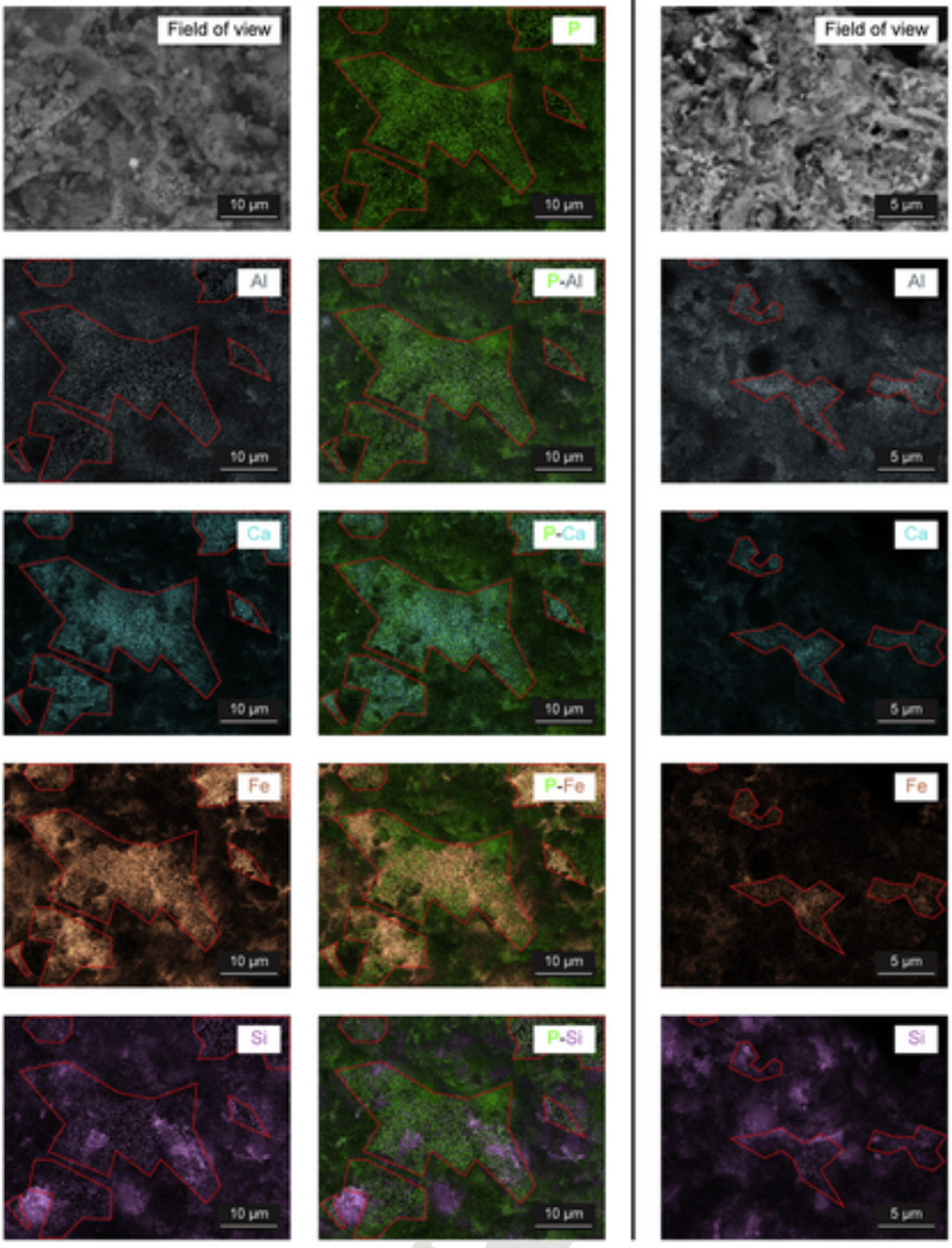

(b) Mapping 2
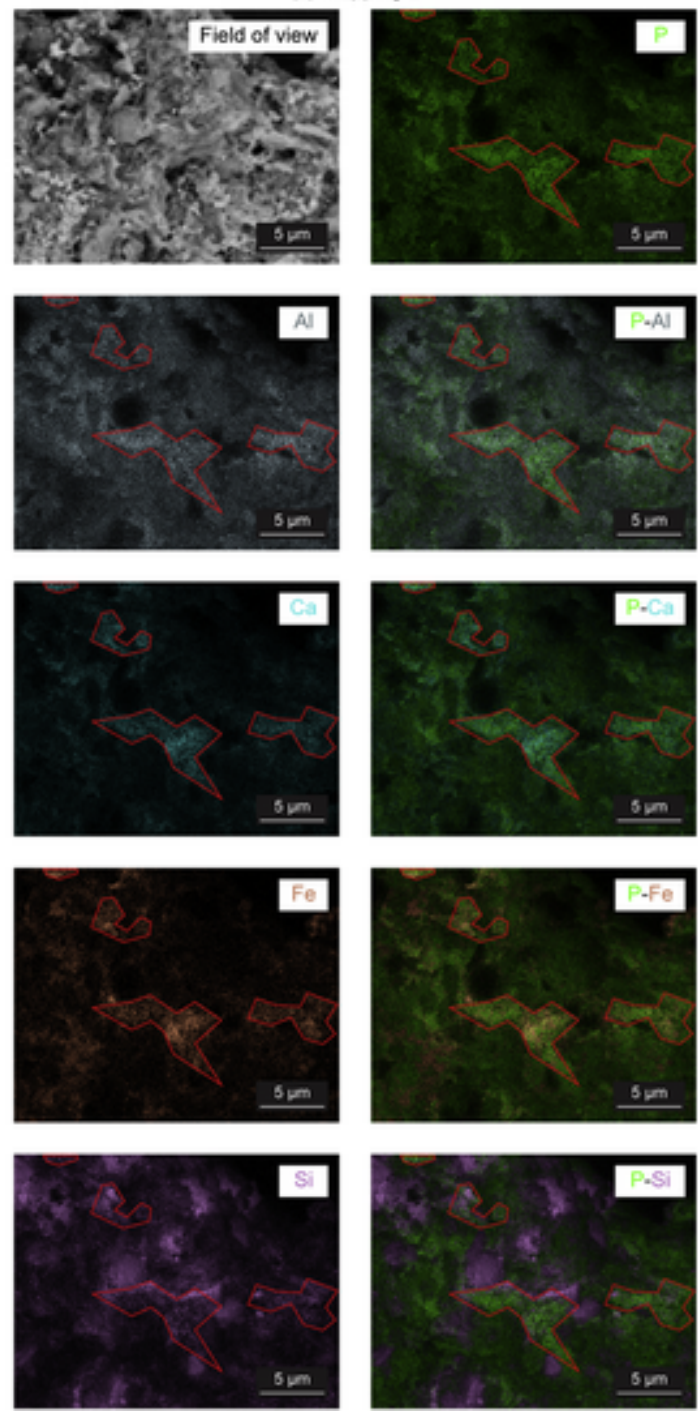

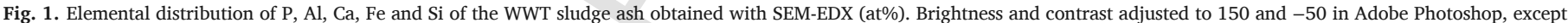
for the field of view. (a) Mapping 1, magnification 1200; (b) Mapping 2, magnification 2500.

soluble $\quad \mathrm{CaSO}_{4} \quad\left(\mathrm{~K}_{\mathrm{sp}}=4.93 \times 10^{-5}\right) \quad$ and $\quad$ Ca-oxalate $\left(\mathrm{K}_{\mathrm{sp}}=2.32 \times 10^{-9}\right)$ enhances the dissolution of Ca-phosphates, thus increasing the $P$ extraction efficiency (see Eqs. (3) and (4)) (Atienza-Martínez et al., 2014; Kootstra et al., 2019). Based on the solubility product values $\left(\mathrm{K}_{\mathrm{sp}}\right)$, higher $\mathrm{P}$ extraction efficiencies are expected for oxalic acid than for $\mathrm{H}_{2} \mathrm{SO}_{4}$, due to a more pronounced shift to the right of Eq. (3) than of Eq. (4). However, according to Fig. 2, the $\mathrm{P}$ extraction efficiency for both extraction liquids is quite similar. This can be explained by deposition of $\mathrm{CaSO}_{4}$ and $\mathrm{Ca}$-oxalate on the ash particles that forms a physical barrier for acid penetration towards the core of the particle, in this way decreasing the $\mathrm{P}$ extraction efficiency (Atienza-Martínez et al., 2014; Cohen, 2009; Donatello et al., 2010b; Fang et al., 2018b).

$3 \mathrm{H}_{2} \mathrm{C}_{2} \mathrm{O}_{4}+\mathrm{Ca}_{3}\left(\mathrm{PO}_{4}\right)_{2} \rightarrow 3 \mathrm{CaC}_{2} \mathrm{O}_{4} \downarrow+2 \mathrm{H}_{3} \mathrm{PO}_{4}$
$3 \mathrm{H}_{2} \mathrm{SO}_{4}+\mathrm{Ca}_{3}\left(\mathrm{PO}_{4}\right)_{2} \rightarrow 3 \mathrm{CaSO}_{4} \downarrow+2 \mathrm{H}_{3} \mathrm{PO}_{4}$

Fig. 2 also shows that with acetic, citric, formic and gluconic acid the $\mathrm{P}$ extraction efficiency was lower than with the inorganic acids and oxalic acid. A first explanation for this is that oxalic acid is the strongest naturally occurring organic acid $\left(\mathrm{pK}_{\mathrm{a} 1}=1.25\right)$ (Kootstra et al., 2019). Another theoretical explanation based on chemical equilibriums is given in Section 3.3.

Appendix A in the Supplementary Material gives the extraction efficiencies of $\mathrm{Al}, \mathrm{Ca}, \mathrm{Cd}, \mathrm{Cr}, \mathrm{Cu}, \mathrm{Fe}, \mathrm{K}, \mathrm{Mg}, \mathrm{Ni}, \mathrm{Pb}, \mathrm{Si}$ and $\mathrm{Zn}$ from the WWT sludge ash in the sixteen randomized runs. Just as for $\mathrm{P}$, the extraction efficiency of these elements was higher with $\mathrm{H}_{2} \mathrm{SO}_{4}, \mathrm{HCl}, \mathrm{HNO}_{3}$ and oxalic acid than with the other extraction liquids. Exceptions were the $\mathrm{Ca}$ and $\mathrm{Pb}$ extraction efficiency with $\mathrm{H}_{2} \mathrm{SO}_{4}$ and oxalic acid and the $\mathrm{Cd}$ extraction efficiency with oxalic acid.

For all the extraction liquids considered, second-order polynomial regression models (see Eq. (1)) were derived to predict responses of $\mathrm{P}$ and $\mathrm{Al}, \mathrm{Ca}, \mathrm{Cd}, \mathrm{Cr}, \mathrm{Cu}, \mathrm{Fe}, \mathrm{K}, \mathrm{Mg}, \mathrm{Ni}, \mathrm{Pb}, \mathrm{Si}$ and $\mathrm{Zn}$ extraction efficiency as function of the extraction liquid concentration $\left(\mathrm{X}_{1}\right), \mathrm{L} /$ $\mathrm{S}$ ratio $\left(\mathrm{X}_{2}\right)$ and contact time $\left(\mathrm{X}_{3}\right)$. Table 5 gives the coefficients of the highly significant second-order polynomial regression models for $\mathrm{P}$ (ANOVA p-value $<0.0001$ and relatively high $\mathrm{R}^{2}$ values). For acetic acid, gluconic acid, oxalic acid, $\mathrm{NaOH}, \mathrm{NTA}+\mathrm{NaOH}, \mathrm{Na}_{2}$-EDTA and $\mathrm{Na}_{4}$-EDTA the selected model fits the data well as there is no evidence of lack of fit (LOF) (p-value >0.05). In contrast, increasing the complexity of the model for $\mathrm{H}_{2} \mathrm{SO}_{4}, \mathrm{HCl}, \mathrm{HNO}_{3}$, citric acid, formic acid and EDTA $+\mathrm{NaOH}$ can possibly fit the data more adequately as there is evidence of LOF (p-value <0.05) (Christensen, 2016). However, based 


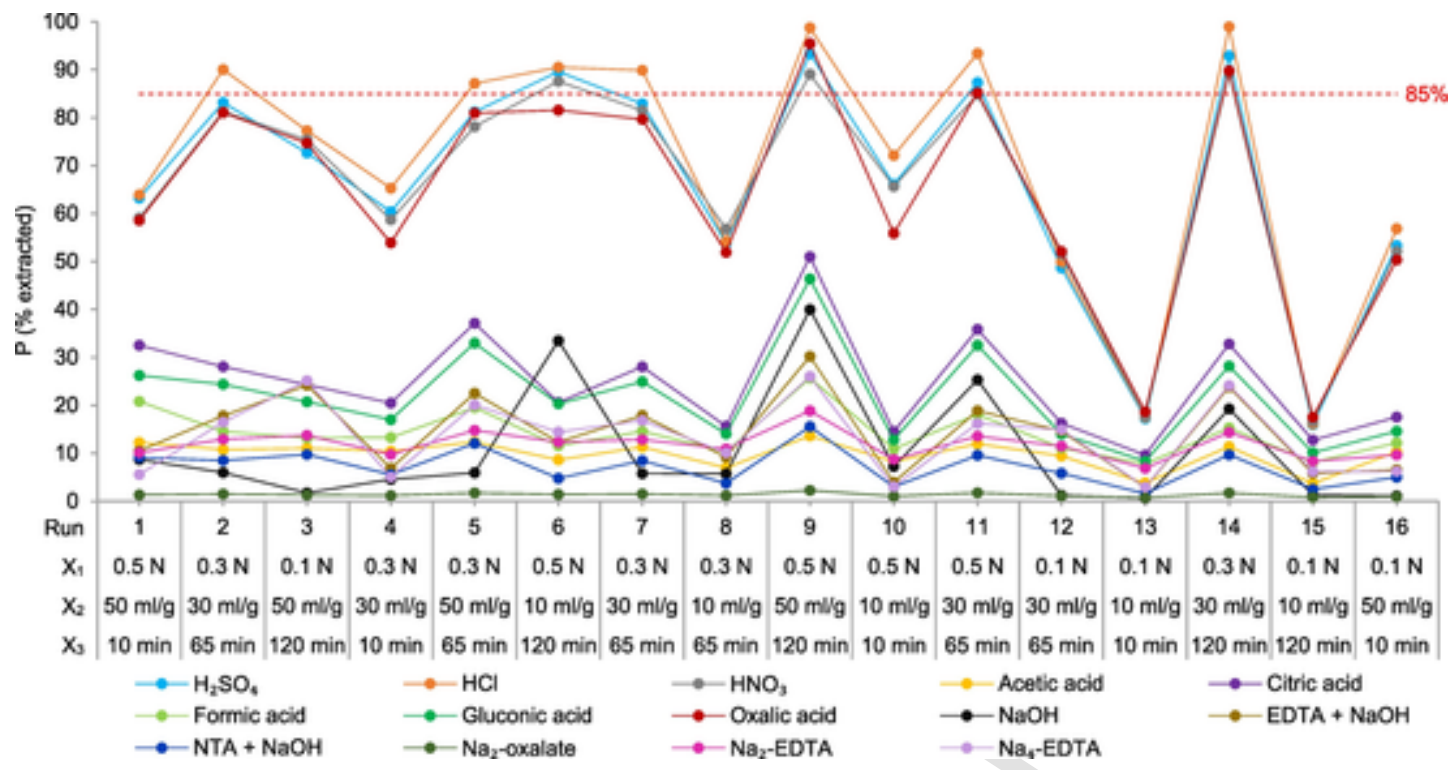

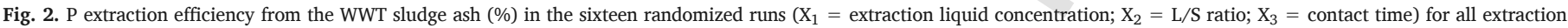

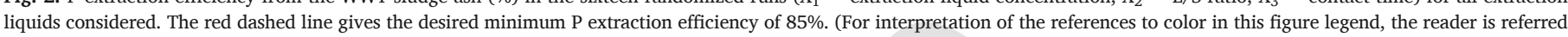
to the web version of this article.)

Table 4

Reported P extraction efficiencies from WWT sludge ash by $\mathrm{H}_{2} \mathrm{SO}_{4}, \mathrm{HCl}, \mathrm{HNO}_{3}$ and oxalic acid extraction.

\begin{tabular}{|c|c|c|c|}
\hline $\begin{array}{l}\text { Extraction } \\
\text { liquid }\end{array}$ & $\begin{array}{l}\text { Extraction } \\
\text { conditions }\end{array}$ & $\begin{array}{l}\text { P extraction } \\
\text { efficiency }\end{array}$ & Reference \\
\hline $\mathrm{H}_{2} \mathrm{SO}_{4}$ & $\begin{array}{l}0.5 \mathrm{~N}, 50 \mathrm{ml} / \mathrm{g}, \\
120 \mathrm{~min}\end{array}$ & $93 \%$ & This work \\
\hline $\mathrm{H}_{2} \mathrm{SO}_{4}$ & $\begin{array}{l}0.4 \mathrm{~N}, 20 \mathrm{ml} / \mathrm{g} \\
120 \mathrm{~min}\end{array}$ & $94 \%$ & Fang et al., 2018b \\
\hline $\mathrm{H}_{2} \mathrm{SO}_{4}$ & $\begin{array}{l}0.38 \mathrm{~N}, 20 \mathrm{ml} / \mathrm{g} \\
120 \mathrm{~min}\end{array}$ & $72-91 \%$ & $\begin{array}{l}\text { Donatello et al., } \\
2010 \text { b }\end{array}$ \\
\hline $\mathrm{H}_{2} \mathrm{SO}_{4}$ & $\begin{array}{l}0.5 \mathrm{~N}, 30 \mathrm{ml} / \mathrm{g} \\
120 \mathrm{~min}\end{array}$ & $82 \%$ & Liang et al., 2019 \\
\hline $\mathrm{HCl}$ & $\begin{array}{l}0.3 \mathrm{~N}, 30 \mathrm{ml} / \mathrm{g}, \\
120 \mathrm{~min}\end{array}$ & $99 \%$ & This work \\
\hline $\mathrm{HCl}$ & $\begin{array}{l}0.5 \mathrm{~N}, 50 \mathrm{ml} / \mathrm{g}, \\
120 \mathrm{~min}\end{array}$ & $95 \%$ & Xu et al., 2012 \\
\hline $\mathrm{HNO}_{3}$ & $\begin{array}{l}0.3 \mathrm{~N}, 30 \mathrm{ml} / \mathrm{g}, \\
120 \mathrm{~min}\end{array}$ & $89 \%$ & This work \\
\hline $\mathrm{HNO}_{3}$ & $\begin{array}{l}0.2 \mathrm{~N}, 20 \mathrm{ml} / \mathrm{g} \\
120 \mathrm{~min}\end{array}$ & $83 \%$ & Fang et al., 2018b \\
\hline Oxalic acid & $\begin{array}{l}0.5 \mathrm{~N}, 50 \mathrm{ml} / \mathrm{g}, \\
120 \mathrm{~min}\end{array}$ & $95 \%$ & This work \\
\hline Oxalic acid & $\begin{array}{l}0.4 \mathrm{~N}, 20 \mathrm{ml} / \mathrm{g}, \\
120 \mathrm{~min}\end{array}$ & $95 \%$ & Fang et al., 2018b \\
\hline Oxalic acid & $\begin{array}{l}0.5 \mathrm{~N}, 30 \mathrm{ml} / \mathrm{g}, \\
120 \mathrm{~min}\end{array}$ & $93 \%$ & Liang et al., 2019 \\
\hline
\end{tabular}

on the "Actual by Predicted Plots" and "Residual by Predicted Plots" generated by the JMP software, these models with evidence of LOF appeared still acceptable to use for the multi-criteria optimizations. Table 5 also shows that the interactions between the variables have a significant effect on the $\mathrm{P}$ extraction efficiency, although to a lesser extent than the variables themselves. This is the case for all extraction liquids considered, except $\mathrm{NaOH}$ that has a relatively low coefficient for L/S ratio $\left(\mathrm{b}_{2}\right)$. For all other elements ( $\mathrm{Al}, \mathrm{Ca}, \mathrm{Cd}, \mathrm{Cr}, \mathrm{Cu}, \mathrm{Fe}, \mathrm{K}, \mathrm{Mg}, \mathrm{Ni}, \mathrm{Pb}, \mathrm{Si}$ and $\mathrm{Zn}$ ), regression model coefficients, $\mathrm{R}^{2}$, ANOVA p-values and LOF p-values are given in Appendix B in the Supplementary Material. Appendix C in the Supplementary Material gives the contour plots of the $\mathrm{P}$ extraction efficiency from the sludge ash for $\mathrm{H}_{2} \mathrm{SO}_{4}, \mathrm{HCl}, \mathrm{HNO}_{3}$ and oxalic acid.

\subsection{Effect of $p H$ on $P$ extraction}

The $\mathrm{pH}$ of the extraction liquids at the start and at the end of the extraction procedure is given in Appendix D in the Supplementary Material. The WWT sludge ash considered was slightly alkaline $(\mathrm{pH}=8.91 \pm 0.01)$ and hence slightly increased the $\mathrm{pH}$ of the inorganic and organic acid extraction liquids during the extraction procedure. Conversely, the $\mathrm{pH}$ of the EDTA $+\mathrm{NaOH}, \mathrm{NTA}+\mathrm{NaOH}$ and $\mathrm{Na}_{2}$-oxalate extraction liquids slightly decreased during the extraction procedure, whereas the $\mathrm{pH}$ of the $\mathrm{NaOH}, \mathrm{Na}_{2}$-EDTA and $\mathrm{Na}_{4}$-EDTA extraction liquids remained almost unchanged.

The $\mathrm{P}$ extraction efficiency in Fig. 2 can be linked to the $\mathrm{pH}$ of the extraction liquids at the end of the extraction procedure (see Appendix $\mathrm{D}$ in the Supplementary Material). This shows that a lower $\mathrm{pH}$ generally results in a higher $\mathrm{P}$ extraction efficiency. More specifically, $\mathrm{P}$ extraction efficiencies $>85 \%$ can only be obtained at a $\mathrm{pH}<2$. This finding is in line with the work of Cohen (2009), Franz (2008), Fang et al. (2018b), Petzet et al. (2012) and Pettersson et al. (2008), who obtained optimal $\mathrm{P}$ extraction efficiencies at a $\mathrm{pH}<3$, depending on the type of incineration ash. The effect of the $\mathrm{pH}$ on the $\mathrm{P}$ extraction efficiency can be explained based on $\mathrm{K}_{\mathrm{sp}}$ values and chemical equilibriums in the extraction solutions. The sludge ash has a complex composition (see Table 2) and upon dissolution, many different cations and anions can interact to eventually reach chemical equilibrium. For the sake of clarity, the explanation below only considers the equilibrium mechanisms of the main $\mathrm{P}$ containing minerals present in the ash for which $\mathrm{K}_{\text {sp }}$ values could be obtained from literature, i.e., $\mathrm{Ca}_{3}\left(\mathrm{PO}_{4}\right)_{2}$ and $\mathrm{AlPO}_{4}$. Both $\mathrm{Ca}_{3}\left(\mathrm{PO}_{4}\right)_{2}$ and $\mathrm{AlPO}_{4}$ have low $\mathrm{K}_{\text {sp }}$ values $\left(2.07 \times 10^{-33}\right.$ and $9.84 \times 10^{-21}$, respectively) and hence have low solubility. However, in a strong acid solution, the (little) $\mathrm{PO}_{4}^{3-}$ dissolving from $\mathrm{Ca}_{3}\left(\mathrm{PO}_{4}\right)_{2}$ and $\mathrm{AlPO}_{4}$ protonates and forms hydrogen phosphates $\left(\mathrm{HPO}_{4}^{2-}\right.$ or $\mathrm{H}_{2} \mathrm{PO}_{4}^{-}$ , see Eqs. (5) and (6)). As a result, the concentration of $\mathrm{PO}_{4}^{3-}$ in solution decreases and following Le Chatelier's principle, the system will compensate this decrease by dissolving more $\mathrm{PO}_{4}^{3-}$ from $\mathrm{Ca}_{3}\left(\mathrm{PO}_{4}\right)_{2}$ and $\mathrm{AlPO}_{4}$ in the ash. The newly dissolved $\mathrm{PO}_{4}^{3-}$ will also protonate and Le Chatelier's principle will continue as long as there is enough acid present (Vitz et al., 2019). Moreover, the hydrogen phosphates are likely to bind with metal ions in solution (e.g., $\mathrm{Ca}^{2+}$ or $\mathrm{Al}^{3+}$ ). The formed metal hydrogen phosphates have in general higher $\mathrm{K}_{\mathrm{sp}}$ values than their 
Table 5

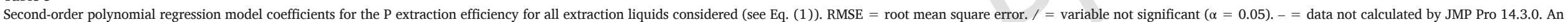
ANOVA p-value $<0.05$ indicates that the prediction model is highly significant. A LOF p-value $<0.05$ indicates that there is evidence of LOF.

\begin{tabular}{|c|c|c|c|c|c|c|c|c|c|c|c|c|c|c|}
\hline & $\mathrm{H}_{2} \mathrm{SO}_{4}$ & $\mathrm{HCl}$ & $\mathrm{HNO}_{3}$ & Acetic acid & Citric acid & Formic acid & Gluconic acid & Oxalic acid & $\mathrm{NaOH}$ & $\mathrm{EDTA}+\mathrm{NaOH}$ & $\mathrm{NTA}+\mathrm{NaOH}$ & $\mathrm{Na}_{2}$-oxalate & $\mathrm{Na}_{2}$-EDTA & $\mathrm{Na}_{4}$-EDTA \\
\hline $\mathrm{b}_{0}$ & 79.2 & 85.1 & 77.7 & 10.9 & 24.8 & 14.7 & 23.8 & 76.5 & 8.0 & 17.6 & 8.3 & 1.53 & 13.0 & 15.8 \\
\hline $\mathrm{b}_{1}$ & 19.2 & 20.1 & 17.3 & 1.6 & 7.4 & 3.5 & 7.0 & 16.3 & 10.9 & 2.2 & 1.7 & 0.29 & 1.3 & / \\
\hline $\mathrm{b}_{2}$ & 12.1 & 13.3 & 10.9 & 2.8 & 8.9 & 4.3 & 7.5 & 13.5 & 0.9 & 6.0 & 3.6 & 0.24 & 2.0 & 4.6 \\
\hline $\mathrm{b}_{3}$ & 10.4 & 10.6 & 10.4 & 0.3 & 4.7 & 0.9 & 4.7 & 12.2 & 7.3 & 6.6 & 1.8 & 0.23 & 2.2 & 7.3 \\
\hline$b_{12}$ & -11.5 & -12.6 & -12.3 & -0.6 & 3.6 & 1.8 & 2.8 & -9.0 & / & I & 0.8 & / & / & / \\
\hline$b_{13}$ & / & / & 1 & / & / & 0.5 & 2.5 & 4.9 & 7.0 & / & / & 0.11 & 0.9 & / \\
\hline$b_{23}$ & I & / & / & / & / & 0.6 & 2.1 & 4.6 & / & 3.3 & 1.1 & 0.10 & 1.0 & 3.1 \\
\hline $\mathrm{b}_{11}$ & -10.0 & -11.4 & -9.5 & / & 1 & 1 & 1 & -8.8 & 4.3 & / & -0.9 & -0.14 & -0.7 & / \\
\hline $\mathrm{b}_{22}$ & -10.6 & -12.5 & -10.2 & -1.8 & 1 & 1 & / & -11.0 & -3.1 & -2.4 & I & / & / & / \\
\hline$b_{33}$ & / & / & / & $/$ & 1 & -0.8 & -3.3 & $/$ & 2.9 & -3.0 & -1.0 & -0.13 & -1.2 & -3.9 \\
\hline $\mathrm{R}^{2}$ & 0.95 & 0.95 & 0.95 & 0.98 & 0.91 & 0.99 & 0.97 & 0.98 & 0.99 & 0.98 & 0.99 & 0.97 & 0.99 & 0.93 \\
\hline RMSE & 6.8 & 7.8 & 6.6 & 0.5 & 3.8 & 0.5 & 2.4 & 5.2 & 2.0 & 1.6 & 0.6 & 0.1 & 0.4 & 2.5 \\
\hline ANOVA p-value & $<0.0001$ & $<0.0001$ & $<0.0001$ & $<0.0001$ & $<0.0001$ & $<0.0001$ & $<0.0001$ & $<0.0001$ & $<0.0001$ & $<0.0001$ & $<0.0001$ & $<0.0001$ & $<0.0001$ & $<0.0001$ \\
\hline LOF p-value & 0.018 & 0.013 & 0.014 & 0.558 & 0.003 & 0.037 & 0.115 & 0.133 & 0.053 & 0.029 & 0.053 & - & 0.125 & 0.290 \\
\hline
\end{tabular}


equivalent metal phosphates. For example, the $\mathrm{K}_{\mathrm{sp}}$ value for $\mathrm{CaHPO}_{4}$ is $1.26 \times 10^{-7}$ compared to $2.07 \times 10^{-33}$ for $\mathrm{Ca}_{3}\left(\mathrm{PO}_{4}\right)_{2}$. Hence, these metal hydrogen phosphates almost completely dissolve in a strong acid solution. Furthermore, it should be noted that the molar solubility (s) of $\mathrm{Ca}_{3}\left(\mathrm{PO}_{4}\right)_{2}\left(1.14 \times 10^{-7} \mathrm{M}\right.$, see Eq. (7)) is higher compared to the molar solubility of $\mathrm{AlPO}_{4}\left(9.92 \times 10^{-11} \mathrm{M}\right.$, see Eq. (8)). Besides, less hydrogen phosphates form in a less acidic solution. Therefore, at less acidic $\mathrm{pH}(\mathrm{pH}>2), \mathrm{Ca}_{3}\left(\mathrm{PO}_{4}\right)_{2}$ shows a higher solubility than $\mathrm{AlPO}_{4}$, which can be generalized for other Al- and Ca-phosphates. Accordingly, this also explains the lower P extraction efficiency obtained with acetic, citric, formic and gluconic acid compared to the inorganic acids and oxalic acid. The organic extraction liquids (except oxalic acid) had a higher $\mathrm{pH}$ at the start and at the end of the extraction procedure (see Appendix $\mathrm{D}$ in the Supplementary Material). Therefore, less hydrogen phosphates were formed during extraction and hence less $\mathrm{AlPO}_{4}\left(\right.$ and $\left.\mathrm{Ca}_{3}\left(\mathrm{PO}_{4}\right)_{2}\right)$ dissolved. Correspondingly, mainly the presence of the Al-phosphates in the sludge ash implies that only at a $\mathrm{pH}<2$ a $\mathrm{P}$ extraction efficiency $>85 \%$ can be obtained. Finally, in an alkaline solution, the (little) $\mathrm{Al}^{3+}$ dissolving from $\mathrm{AlPO}_{4}$ forms a complexion with $\mathrm{OH}^{-}\left(\mathrm{Al}(\mathrm{OH})_{4}^{-}\right)$(see Eq. (9)) which shifts Eq. (8) to the right following Le Chatelier's principle. As a result, this equilibrium shift will be compensated by dissolving more $\mathrm{AlPO}_{4}$. In contrast, $\mathrm{Ca}^{2+}$ does not form hydroxide complexes in an alkaline environment, which explains why $\mathrm{Ca}_{3}\left(\mathrm{PO}_{4}\right)_{2}$ does not dissolve in an alkaline solution.

$$
\begin{aligned}
& \mathrm{PO}_{4}^{3-}+\mathrm{H}_{3} \mathrm{O}^{+} \rightleftharpoons \mathrm{HPO}_{4}^{2-}+\mathrm{H}_{2} \mathrm{O} \quad \mathrm{pK}_{\mathrm{a}}=12.67 \\
& \mathrm{HPO}_{4}^{2-}+\mathrm{H}_{3} \mathrm{O}^{+} \rightleftharpoons \mathrm{H}_{2} \mathrm{PO}_{4}^{-}+\mathrm{H}_{2} \mathrm{O} \quad \mathrm{pK}_{\mathrm{a}}=7.21 \\
& \mathrm{Ca}_{3}\left(\mathrm{PO}_{4}\right)_{2} \rightleftharpoons 3 \mathrm{Ca}^{2+}+2 \mathrm{PO}_{4}^{3-} \quad \mathrm{K}_{\mathrm{sp}} \\
& =2.07 \times 10^{-33} \quad \mathrm{~K}_{\mathrm{sp}} \\
& =\left[\mathrm{Ca}^{2+}\right]^{3}\left[\mathrm{PO}_{4}^{3-}\right]^{2} \\
& =(3 \mathrm{~s})^{3}\left(2 \mathrm{~s}^{2}\right. \\
& =108 \mathrm{~s}^{5} \\
& \mathrm{AlPO}_{4} \rightleftharpoons \mathrm{Al}^{3+}+\mathrm{PO}_{4}^{3-} \quad \mathrm{K}_{\mathrm{sp}} \\
& =9.84 \times 10^{-21} \quad \mathrm{~K}_{\mathrm{sp}} \\
& =\left[\mathrm{Al}^{3+}\right]\left[\mathrm{PO}_{4}^{3-}\right] \\
& =(\mathrm{s})(\mathrm{s}) \\
& =\mathrm{s}^{2} \\
& \mathrm{Al}(\mathrm{OH})_{3}+\mathrm{OH}^{-} \rightleftharpoons \mathrm{Al}(\mathrm{OH})_{4}^{-} \quad \mathrm{K}_{\mathrm{f}}=1.1 \times 10^{33}
\end{aligned}
$$

ciency. From the DOE results, it can be concluded that for the inorganic and organic extraction liquids the $\mathrm{pH}$ at the end of the extraction procedure decreased when variables where changed as follows: (1) increasing extraction liquid concentration, (2) increasing L/S ratio and (3) decreasing contact time. Of these three variables, the contact time had in general the least effect on the $\mathrm{pH}$. Fig. 3 gives the $\mathrm{P}$ extraction efficiency as function of the $\mathrm{pH}$ at the end of the extraction procedure for $\mathrm{HCl}$ and oxalic acid extraction, with the contact time used as overlay factor. Fig. 3a shows that for $\mathrm{HCl}$ extraction, point $\mathrm{x}(0.5 \mathrm{~N}, 50 \mathrm{ml} / \mathrm{g}, 10 \mathrm{~min})$ at $\mathrm{pH} 0.43$ resulted in a $\mathrm{P}$ extraction efficiency of $63.9 \%$, whereas point y $(0.5 \mathrm{~N}, 50 \mathrm{ml} / \mathrm{g}, 120 \mathrm{~min})$ at $\mathrm{pH} 0.46$ resulted in a $\mathrm{P}$ extraction efficiency of $98.8 \%$. Similar results were obtained for oxalic acid (see Fig. 3b): point $\mathrm{x}(0.5 \mathrm{~N}, 50 \mathrm{ml} / \mathrm{g}, 10 \mathrm{~min})$ at $\mathrm{pH} 1.04$ resulted in a $\mathrm{P}$ extraction efficiency of $58.6 \%$, whereas point y $(0.5 \mathrm{~N}, 50 \mathrm{ml} / \mathrm{g}, 120 \mathrm{~min})$ at $\mathrm{pH} 1.08$ resulted in a P extraction efficiency of $95.4 \%$. Hence, the difference in $\mathrm{pH}$ between point $\mathrm{x}$ and $\mathrm{y}$ is rather small, whereas there is a big difference in $\mathrm{P}$ extraction efficiency, mainly due to the longer extraction time. Accordingly, it can be concluded that $\mathrm{pH}$ affects the $\mathrm{P}$ extraction efficiency, however, in combination with the other variables, i.e., extraction liquid concentration, L/S ratio and contact time. Yet, Fig. 3 shows that in general for the same contact time, the P extraction efficiency increases with decreasing $\mathrm{pH}$ at the end of the extraction procedure.

Furthermore, comparing the $\mathrm{P}$ extraction efficiencies obtained with oxalic acid and $\mathrm{Na}_{2}$-oxalate (see Fig. 2 ) indicated that only the presence of oxalate ions was not enough to extract P from the WWT sludge ash. Only between 1 and $2 \%$ of total $\mathrm{P}$ was extracted with $\mathrm{Na}_{2}$-oxalate, whereas this was between 18 and $95 \%$ with oxalic acid. With $\mathrm{Na}_{2}$-oxalate, the $\mathrm{pH}$ at the end of the extraction procedure ranged between 8.1 and 9.3, whereas with oxalic acid it ranged between 1.0 and 4.1. Hence, an acidic environment increases the P extraction efficiency considerably. Although, as stated before, the high P extraction efficiency obtained with the oxalic acid solution is due to both the acidic environment and the presence of oxalate ions (formation of Ca-oxalate), which was also found by Kootstra et al. (2019). Furthermore, $\mathrm{Na}_{2}$-oxalate extraction resulted in relatively low extraction efficiencies of Cd $(<5.2 \%)$, $\mathrm{Cr}(<0.4 \%), \mathrm{Cu}(<5.4 \%), \mathrm{Ni}(<4.5 \%), \mathrm{Pb}(<1.1 \%)$ and $\mathrm{Zn}(<3.1 \%)$. Accordingly, it can be concluded that the higher Cd (1.0-21.3\%), Cr (0.3-12.3\%), Cu (17.0-52.2\%), Ni (6.3-25.5\%), Pb (0.04-3.1\%) and $\mathrm{Zn}$ (14.1-51.3\%) extraction efficiencies obtained with oxalic acid resulted from the more acidic environment compared to extraction with $\mathrm{Na}_{2}$-oxalate.

However, a $\mathrm{pH}<2$ did not always result in a $\mathrm{P}$ extraction efficiency $>85 \%$. This is due to the fact that the extraction liquid concentration, L/S ratio and contact time also affect the $\mathrm{P}$ extraction effi-

(a) $\mathrm{HCl}$

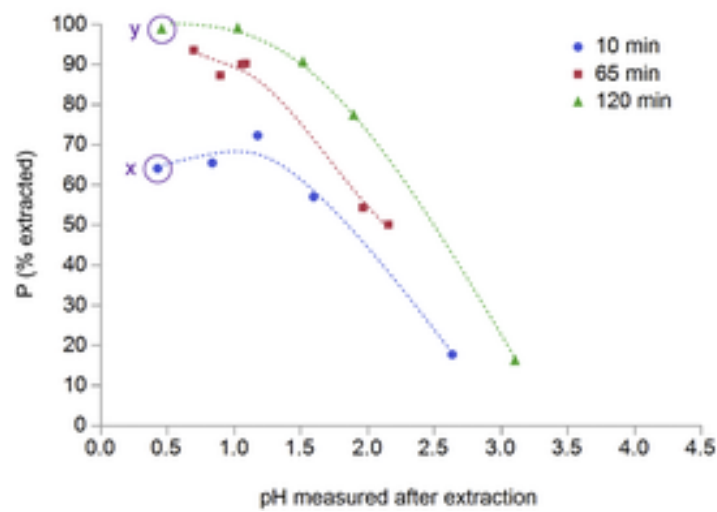

(b) Oxalic acid

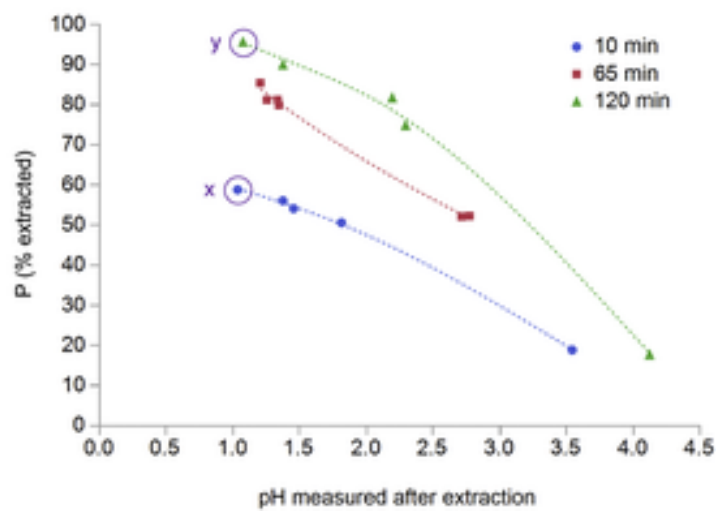

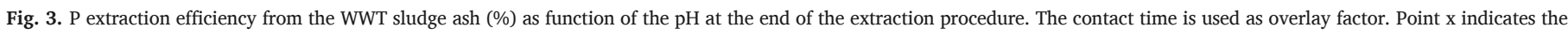

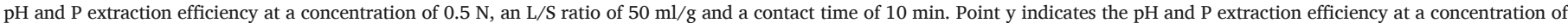
$0.5 \mathrm{~N}$, an $\mathrm{L} / \mathrm{S}$ ratio of $50 \mathrm{ml} / \mathrm{g}$ and a contact time of $120 \mathrm{~min}$. (a) For $\mathrm{HCl}$ extraction; (b) For oxalic acid extraction. 


\subsection{Multi-criteria optimization}

\subsubsection{Optimal $P$ extraction conditions}

Fig. $4 a-c$ give the technological optimal extraction conditions (extraction liquid concentration, $\mathrm{L} / \mathrm{S}$ ratio and contact time) at which the
$\mathrm{P}$ extraction efficiency is maximized and the heavy metal $(\mathrm{Cd}, \mathrm{Cr}, \mathrm{Cu}$, $\mathrm{Ni}, \mathrm{Pb}$ and $\mathrm{Zn}$ ) extraction efficiency is minimized. Fig. $4 \mathrm{~d}-\mathrm{j}$ give the related extraction efficiencies. Based on the P extraction efficiency, $\mathrm{H}_{2} \mathrm{SO}_{4}$, $\mathrm{HCl}, \mathrm{HNO}_{3}$ and oxalic acid were the most interesting extraction liquids, followed by citric acid, gluconic acid and $\mathrm{NaOH}$ (see Fig. 4d). Fig. 5 gives the results of the further multi-criteria techno-economic
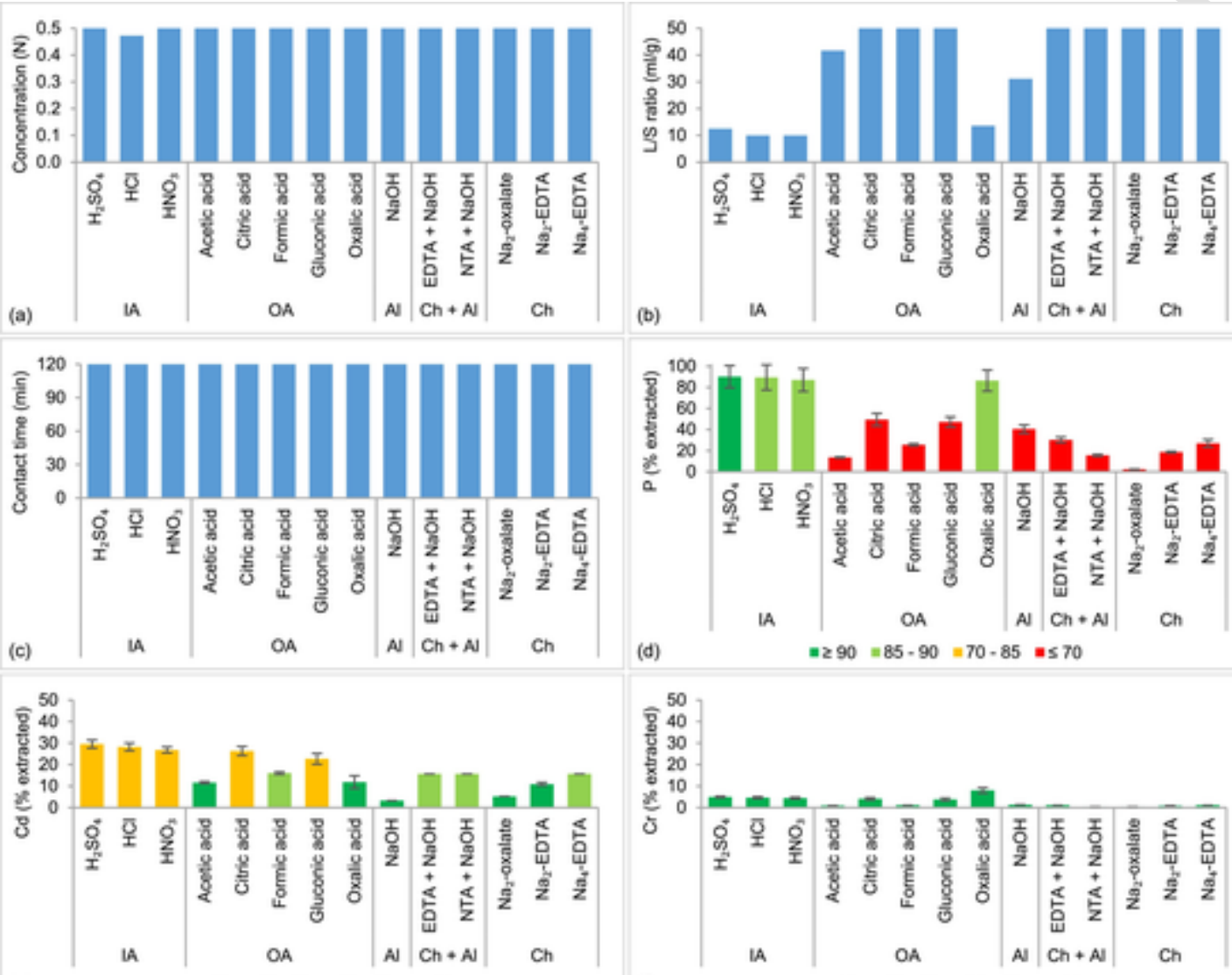

(e) $\quad=\leq 15=15-20=20-30=230$

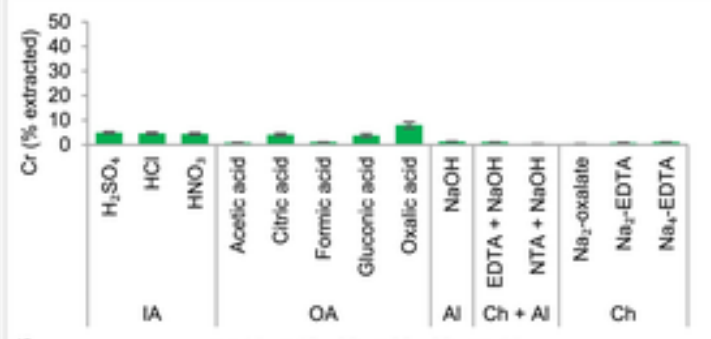

(i)

$\leq 15=15-20=20-30=\geq 30$
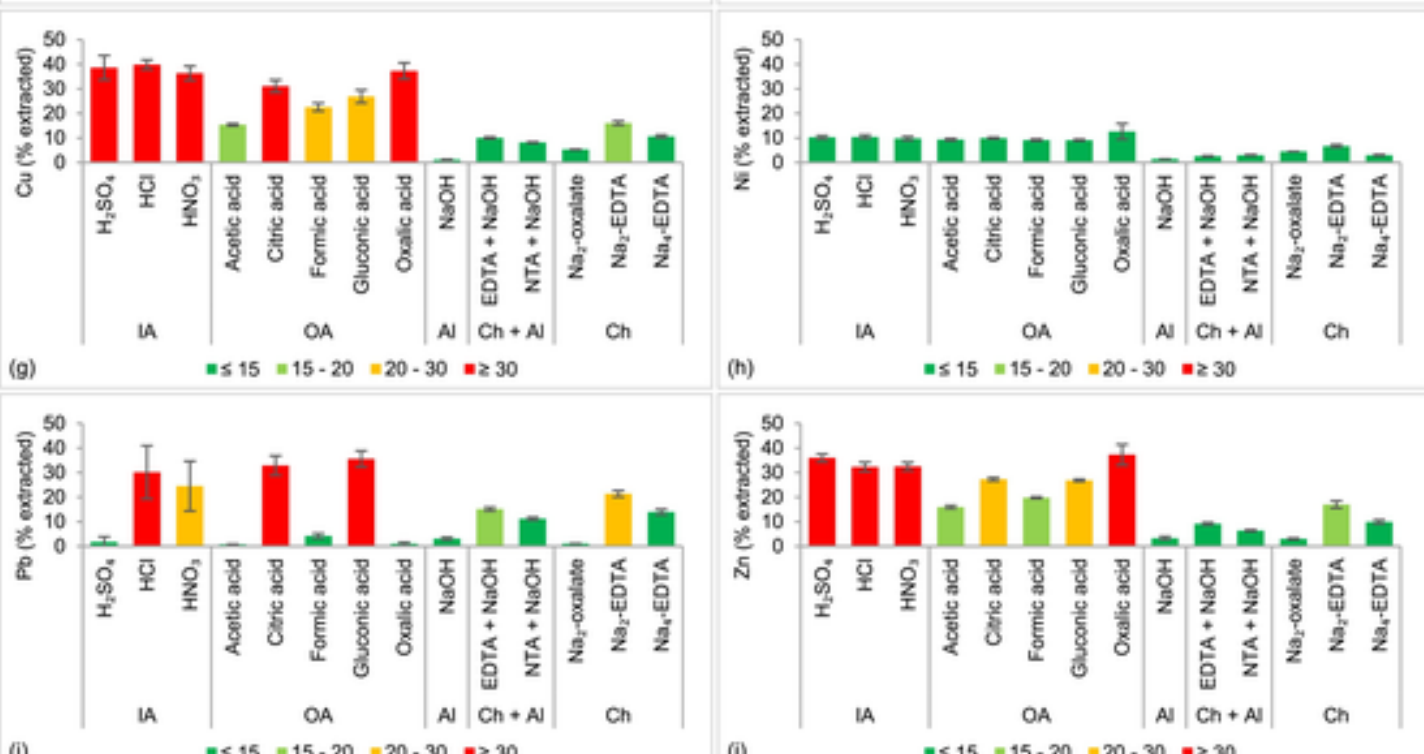

(h)

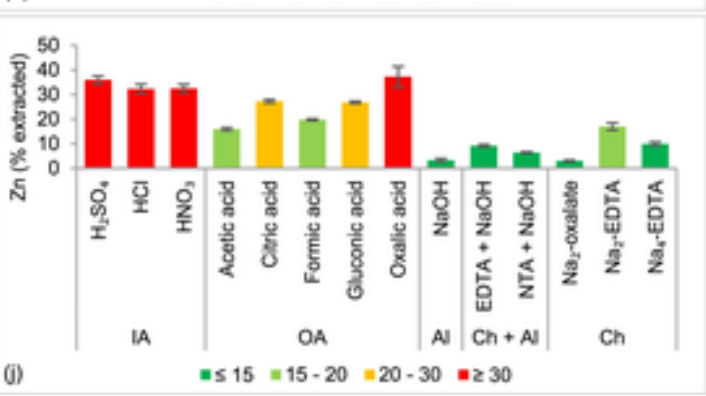

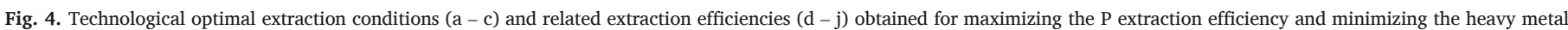

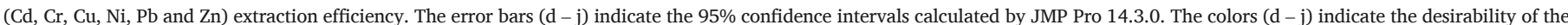

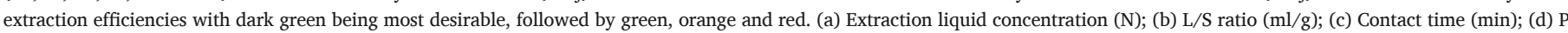

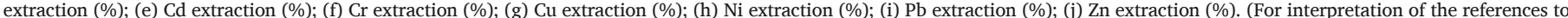
color in this figure legend, the reader is referred to the web version of this article.) 

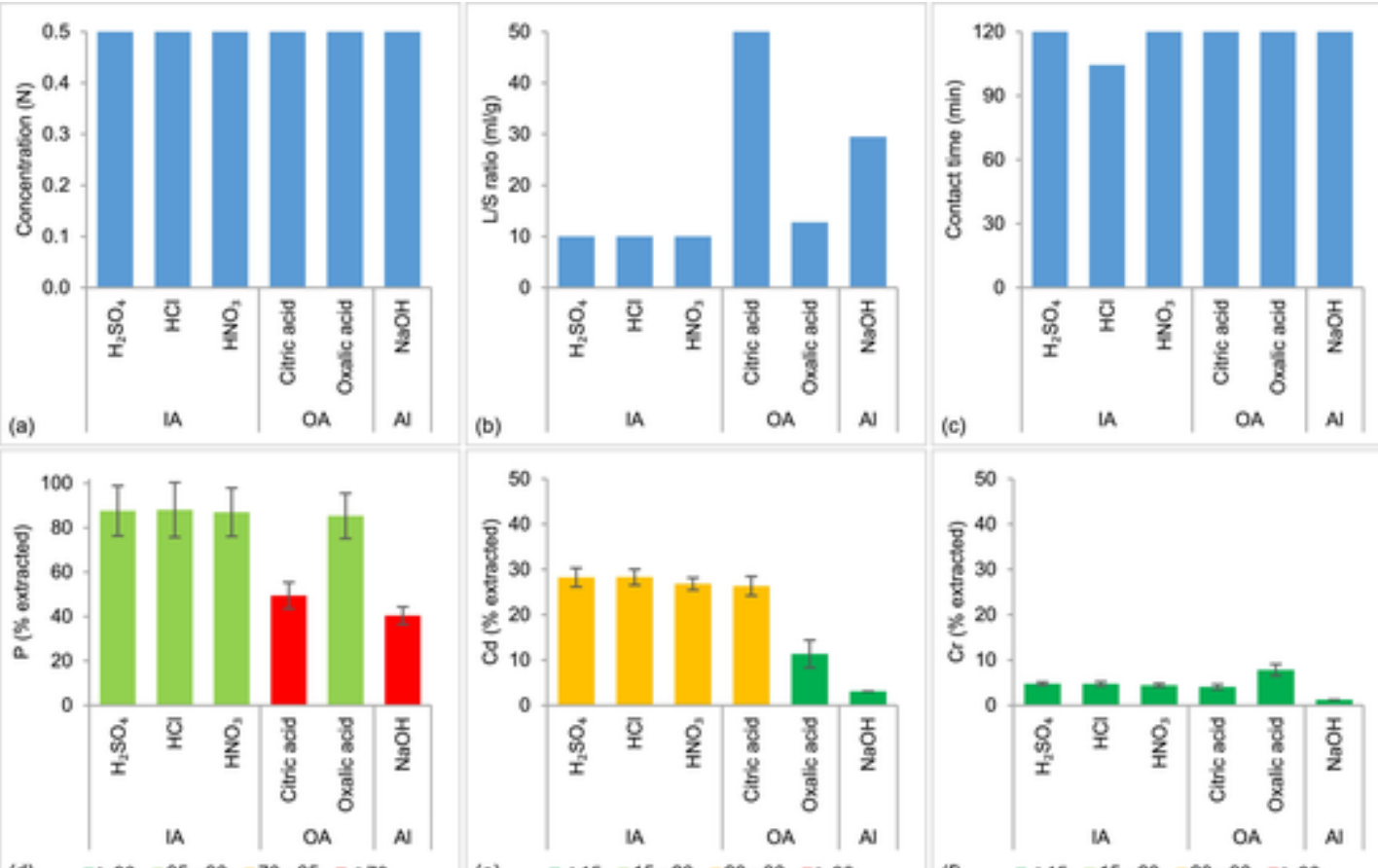

(d) $=\geq 90=85-90=70-85=\leq 70$

(e)

(f) $=\leq 15=15-20=20-30=230$
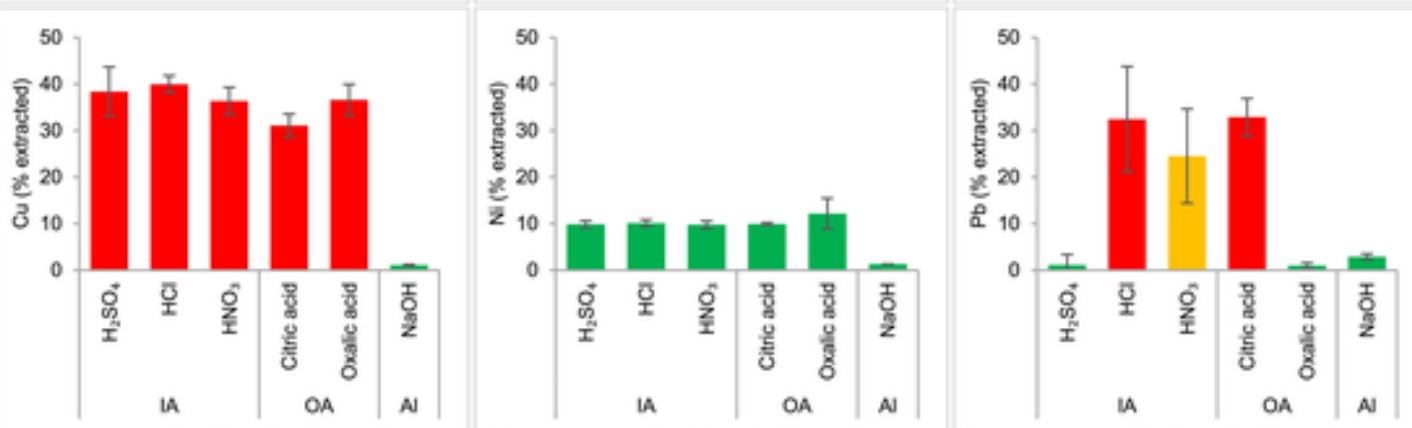

(g) $=\$ 15=15-20=20-30=230$

(h) $=\leq 15=15-20=20-30=230 \quad$ (i)

(i) $=\leq 15=15-20=20-30=230$
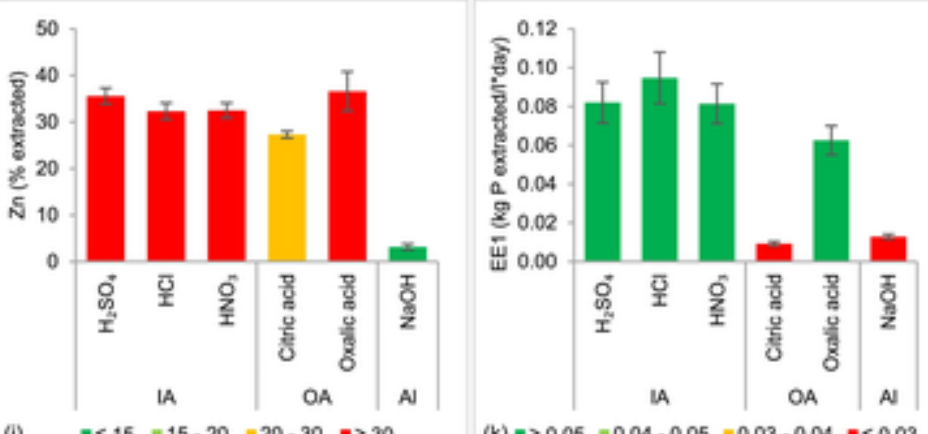

(k) $=20.05=0.04-0.05=0.03-0.04=\leq 0.03$

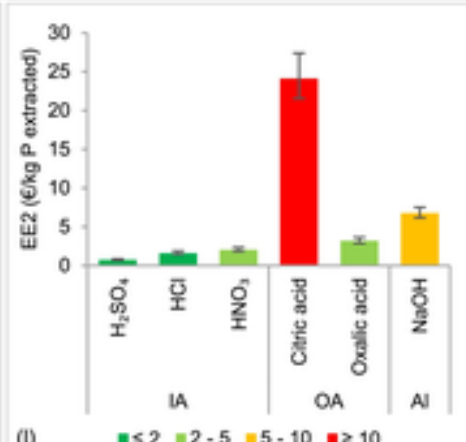

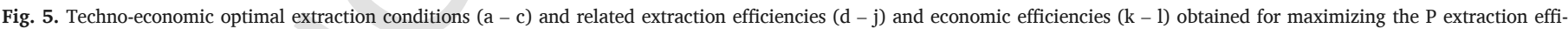

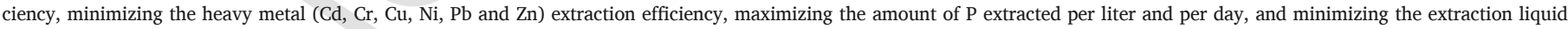

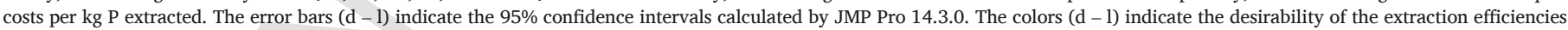

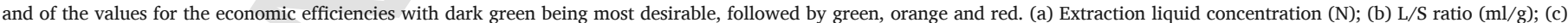

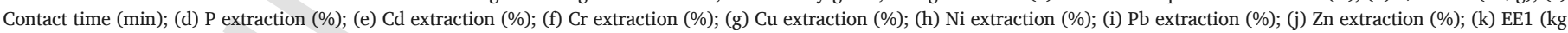
$\mathrm{P}$ extracted/1-day); (l) EE2 ( $€ / \mathrm{kg}$ P extracted). (For interpretation of the references to color in this figure legend, the reader is referred to the web version of this article.)

optimization for these seven extraction liquids, taking into account the cost-efficiency. Data for gluconic acid is not given in Fig. 5 due to its very low extraction liquid cost-efficiency, i.e., $119 € / \mathrm{kg} P$ extracted (Chembid, n.d.). For $\mathrm{HNO}_{3}$ and citric acid, the techno-economic optimal extraction conditions (see Fig. 5a-c) were similar to the technological optimal extraction conditions (see Fig. 4a-c). However, for $\mathrm{H}_{2} \mathrm{SO}_{4}$, oxalic acid and $\mathrm{NaOH}$, a slightly lower $\mathrm{L} / \mathrm{S}$ ratio and for $\mathrm{HCl}$ a slightly lower contact time resulted in a slightly more cost-effective $\mathrm{P}$ extraction. Although, in general, the technological and techno-economic optimal extraction conditions are quite similar.

The further selection of the most optimal extraction liquid was based on the co-extraction of the heavy metals $(\mathrm{Cd}, \mathrm{Cr}, \mathrm{Cu}, \mathrm{Ni}, \mathrm{Pb}$ and $\mathrm{Zn}$ ). $\mathrm{NaOH}$ was the only extraction liquid dissolving almost no heavy metals (see Fig. 5e-j), mainly due to the high $\mathrm{pH}$ at the end of the ex- 
traction procedure (12.5-13.0) (Ali and Kim, 2016; Li et al., 2017; Zhang et al., 2016). However, $\mathrm{NaOH}$ was not effective for P extraction from WWT sludge ash since only $40 \%$ of total P was extracted, which is in line with the findings of Xu et al. (2012) and Biswas et al. (2009). This can be explained by the fact that Al- and Fe-phosphates show high solubility in alkaline environment, whereas Ca-phosphates are not or only slightly soluble in alkaline environment (Ali and Kim, 2016; Petzet et al., 2012). Based on the XRD results, SEM-EDX results and $\mathrm{P}$ extraction efficiency obtained with $\mathrm{NaOH}$, it was estimated that around $40 \%$ of total P is bound as (amorphous) Al-phosphates, whereas the other $60 \%$ is probably bound as Ca-phosphates.

All extraction liquids in Fig. 5 except $\mathrm{NaOH}$ resulted in relatively high $\mathrm{Cd}, \mathrm{Cu}, \mathrm{Pb}$ and $\mathrm{Zn}$ extraction efficiencies (20-40\%), whereas the $\mathrm{Cr}$ and $\mathrm{Ni}$ extraction efficiencies were $<13 \%$ (see Fig. $5 \mathrm{e}-\mathrm{j}$ ). Exceptions are the low $\mathrm{Cd}$ and $\mathrm{Pb}$ extraction efficiency in oxalic acid and the low $\mathrm{Pb}$ extraction efficiency in $\mathrm{H}_{2} \mathrm{SO}_{4}$. These exceptions might be related to the formation of poorly soluble Cd-oxalate $\left(\mathrm{K}_{\mathrm{sp}}=1.42 \times 10^{-8}\right)$, Pb-oxalate $\left(\mathrm{K}_{\mathrm{sp}}=4.8 \times 10^{-10}\right)$ and $\mathrm{PbSO}_{4}\left(\mathrm{~K}_{\mathrm{sp}}=2.53 \times 10^{-8}\right)$ (Huang et al., 2011; Takahashi et al., 2001). The Cd, $\mathrm{Cu}$ and $\mathrm{Zn}$ extraction efficiency were highest for the extraction liquids that also had the highest $\mathrm{P}$ extraction efficiency, i.e., $\mathrm{H}_{2} \mathrm{SO}_{4}, \mathrm{HCl}, \mathrm{HNO}_{3}$ and oxalic acid. Hence, a high $\mathrm{P}$ extraction efficiency from the WWT sludge ash coincides inevitably with high heavy metal co-extraction. Oxalic acid is the best extraction liquid to combine a high P extraction efficiency with relatively low heavy metal co-extraction. Indeed, for oxalic acid extraction, only $\mathrm{Cu}$ and $\mathrm{Zn}$ showed extraction efficiencies of $37 \%$, whereas the $\mathrm{Cd}, \mathrm{Cr}$, $\mathrm{Ni}$ and $\mathrm{Pb}$ extraction efficiencies were $<13 \%$. The lower heavy metal extraction efficiency decreases the process costs for further removal of these unwanted elements. However, from an economic point of view, using oxalic acid as extraction liquid is somewhat less interesting than using one of the inorganic acids. This is due to the lower amount of $\mathrm{P}$ that can be extracted per liter and per day (see Fig. 5k) and the higher extraction liquid costs per $\mathrm{kg} P$ extracted (see Fig. 51). On the one hand, this can be explained by the slightly higher optimal L/S ratio for oxalic acid $(12.8 \mathrm{ml} / \mathrm{g})$ compared to the inorganic acids $(10 \mathrm{ml} / \mathrm{g})$. On the other hand, the extraction liquid costs for oxalic acid $\left(0.033 € / \mathrm{mol} \mathrm{H}^{+}\right)$ are higher compared to the inorganic acids $\left(0.010-0.028 € / \mathrm{mol} \mathrm{H}^{+}\right)$. Therefore, from an economic point of view, extraction with $\mathrm{H}_{2} \mathrm{SO}_{4}$ is most interesting. $\mathrm{H}_{2} \mathrm{SO}_{4}$ extracts high amounts of $\mathrm{P}$ per liter and per day (0.082 kg P extracted/lday, see Fig. 5k), whereas the extraction liquid costs per kg P extracted are the lowest $(0.75 € / \mathrm{kg}$ P extracted, see Fig. 51). Yet, for $\mathrm{H}_{2} \mathrm{SO}_{4}$, a more intense purification of the extraction liquid may be necessary as higher amounts of $\mathrm{Cd}$ are extracted than with oxalic acid (see Fig. 5e). The optimal P extraction efficiency was $88 \%$ for $\mathrm{H}_{2} \mathrm{SO}_{4}$ extraction $(0.5 \mathrm{~N}, 10 \mathrm{ml} / \mathrm{g}$ and $120 \mathrm{~min})$ and $85 \%$ for oxalic acid extraction $(0.5 \mathrm{~N}, 12.8 \mathrm{ml} / \mathrm{g}$ and $120 \mathrm{~min})$, respectively. These P extraction efficiencies are slightly lower than those previously reported in this work and by Fang et al. (2018b) and Liang et al. (2019) (see Table 4) but are compensated by a lower heavy metal co-extraction.

A high $\mathrm{K}$ extraction efficiency was desirable since $\mathrm{P}$ and $\mathrm{K}$ are both fertilizer elements. However, only $29 \%$ of total $\mathrm{K}$ was extracted with $\mathrm{H}_{2} \mathrm{SO}_{4}$ and $27 \%$ with oxalic acid because $\mathrm{K}$ is mainly bound as poorly soluble silicates, retaining the $\mathrm{K}$ in the solid extraction residue. Low $\mathrm{Si}$, $\mathrm{Ca}, \mathrm{Mg}, \mathrm{Al}$ and $\mathrm{Fe}$ extraction efficiencies were desirable so that the solid residue remaining after separation of the extraction liquid has an interesting potential for use as building material or raw material for cement production (Luyckx et al., 2019). Hence, from a technological point of view, the solid extraction residue obtained with oxalic acid had the highest valorization potential since $98 \%$ of total Si, $95 \%$ of total $\mathrm{Ca}$ and $89 \%$ of total $\mathrm{Fe}$ remained in this residue. Si and Fe were mainly found in the solid extraction residue because quartz (and silicates in general), hematite and magnetite are almost insoluble in an acidic environment (Atienza-Martínez et al., 2014; Donatello et al., 2010b; Fang et al., 2018b; Gorazda et al., 2016). Moreover, high amounts of Ca finally remained in the solid extraction residue due to precipitation of Ca-oxalate (Atienza-Martínez et al., 2014; Fang et al., 2018b; Huang et al., 2011; Kootstra et al., 2019). However, only $55 \%$ of total $\mathrm{Al}$ and $21 \%$ of total $\mathrm{Mg}$ were retained in the solid residue of oxalic acid extraction. Yet, $\mathrm{Mg}$ is one of the 27 critical raw materials (European Commission, 2017). Therefore, it could be interesting to extract as much $\mathrm{Mg}$ as possible and recover it from the extract, whether or not together with $\mathrm{P}$ or other elements. For the extraction with $\mathrm{H}_{2} \mathrm{SO}_{4}$, the percentages of total $\mathrm{Si}(98 \%), \mathrm{Fe}(93 \%), \mathrm{Al}(50 \%)$ and $\mathrm{Mg}(26 \%)$ that were retained in the solid extraction residue were similar to those for the extraction with oxalic acid. However, a slightly lower amount of total $\mathrm{Ca}(81 \%)$ was retained with $\mathrm{H}_{2} \mathrm{SO}_{4}$.

It can be concluded that, from an economic point of view, the use of $\mathrm{H}_{2} \mathrm{SO}_{4}$ as extraction liquid is preferred over oxalic acid due to the lower extraction liquid costs for optimal P extraction. However, downstream processing costs (e.g., removal of heavy metals from the extract), environmental impact and overall sustainability of the process also have to be considered for a final selection of extraction liquid. Production of organic acids such as oxalic acid is, for instance, more sustainable than production of $\mathrm{H}_{2} \mathrm{SO}_{4}$ (Kootstra et al., 2019). Furthermore, considerable amounts of $\mathrm{CaSO}_{4}$ and Ca-oxalate are produced when using $\mathrm{H}_{2} \mathrm{SO}_{4}$ and oxalic acid for $\mathrm{P}$ extraction, respectively, for which a suitable application as secondary resource has to be found (Cohen, 2009; Donatello et al., 2010a, 2010b). For example, Donatello et al. (2010a) investigated the use of the solid extraction residue obtained after $\mathrm{P}$ extraction from WWT sludge ash with $\mathrm{H}_{2} \mathrm{SO}_{4}$ in construction materials. They found that the presence of $\mathrm{CaSO}_{4}$ in the solid extraction residue significantly reduced the rate of strength development of these construction materials. No literature was found on the use of the solid extraction residue containing Ca-oxalate in or as construction materials. However, it is expected that the organic fraction in Ca-oxalate is combusted when added to the other raw materials in a cement kiln. Hence, Ca-oxalate will not negatively interfere with the cement properties, in contrast to $\mathrm{CaSO}_{4}$ that is formed upon $\mathrm{H}_{2} \mathrm{SO}_{4}$ extraction.

\subsubsection{Optimal pre-treatment extraction conditions}

The first multi-criteria optimization indicated that a high P extraction efficiency could be obtained from the WWT sludge ash, unfortunately coinciding with high heavy metal co-extraction. For that reason, it was interesting to investigate the possibility to use one of the extraction liquids considered, albeit at a lower concentration, to extract as many heavy metals as possible from the ash as a pre-treatment step. In a next step, $\mathrm{P}$ extraction with $\mathrm{H}_{2} \mathrm{SO}_{4}$ or oxalic acid would then result in lower heavy metal concentrations in the extract, thus reducing the downstream processing costs. Hence, a second multi-criteria optimization was performed aiming at maximizing the heavy metal $(\mathrm{Cd}, \mathrm{Cr}$, $\mathrm{Cu}, \mathrm{Ni}, \mathrm{Pb}$ and $\mathrm{Zn}$ ) extraction efficiency $(>25 \%)$ and minimizing the $\mathrm{P}$ extraction efficiency $(<15 \%)$. However, this second multi-criteria optimization showed that none of the extraction liquids considered met the requirements for use as a pre-treatment extraction liquid (see Fig. 6). There was no extraction liquid for which $>25 \%$ of all heavy metals ( $\mathrm{Cd}, \mathrm{Cr}, \mathrm{Cu}, \mathrm{Ni}, \mathrm{Pb}$ and $\mathrm{Zn}$ ) was extracted from the ash while simultaneously only extracting a maximum amount of $15 \%$ of total P. Therefore, it can be concluded that pre-treatment with one of the extraction liquids considered would only result in a loss of $\mathrm{P}$ and has no or only slightly added value for the removal of heavy metals. The work of Fang et al. (2018a) also showed a considerable co-extraction of P when using EDTA as pre-treatment liquid to extract heavy metals from WWT sludge ash. Based on the data given, the overall $\mathrm{P}$ extraction efficiency in Fang et al.'s (2018a) experiments can be calculated to be $21 \%$ lower in a two-step extraction process (step $1=$ EDTA; step $2=\mathrm{H}_{2} \mathrm{SO}_{4}$ ) than in a single-step extraction process $\left(\mathrm{H}_{2} \mathrm{SO}_{4}\right)$. This is comparable to the $13 \% \mathrm{P}$ that is extracted with EDTA as heavy metal pre-treatment step in this work (see Fig. 6). 

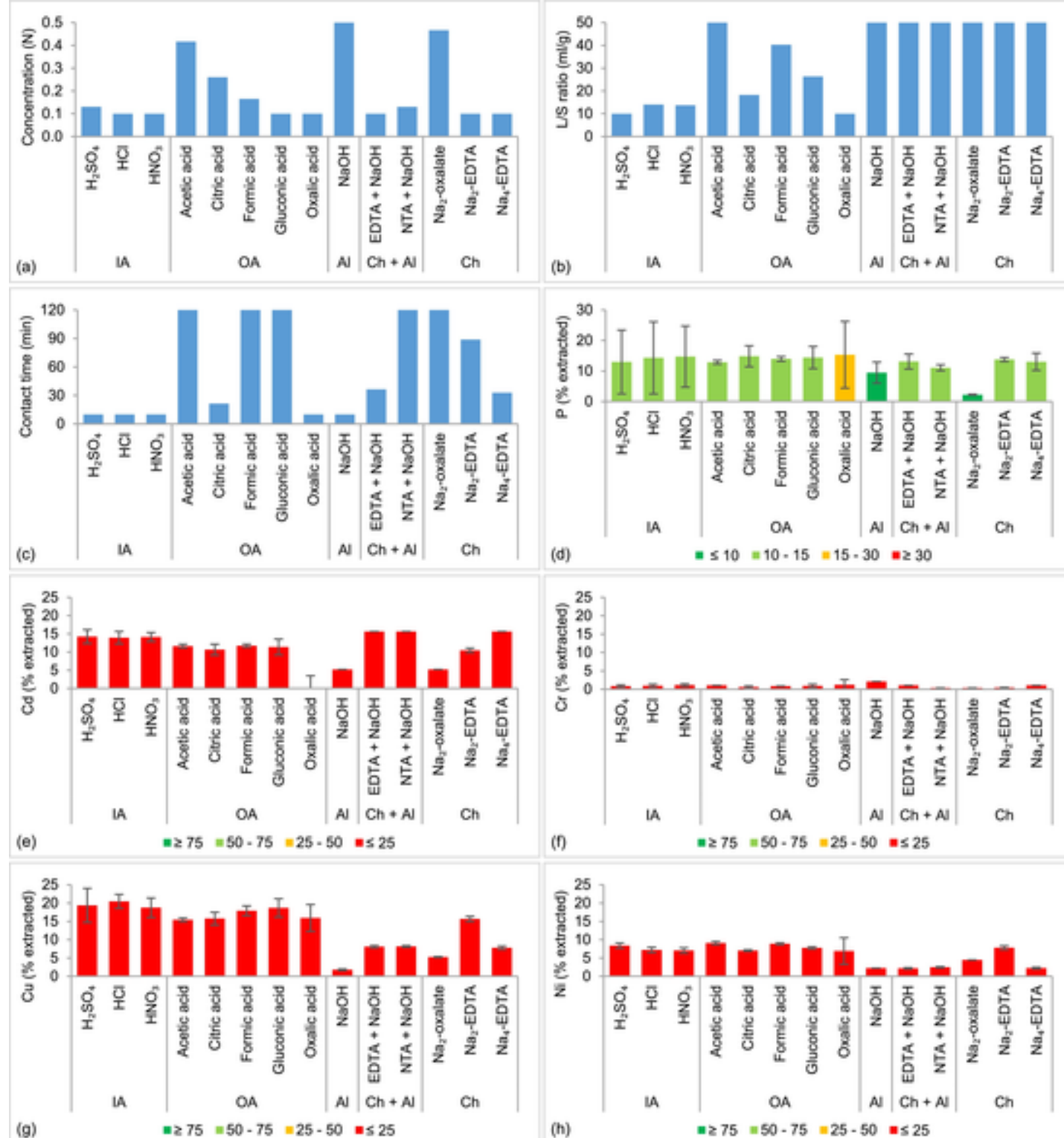

(五
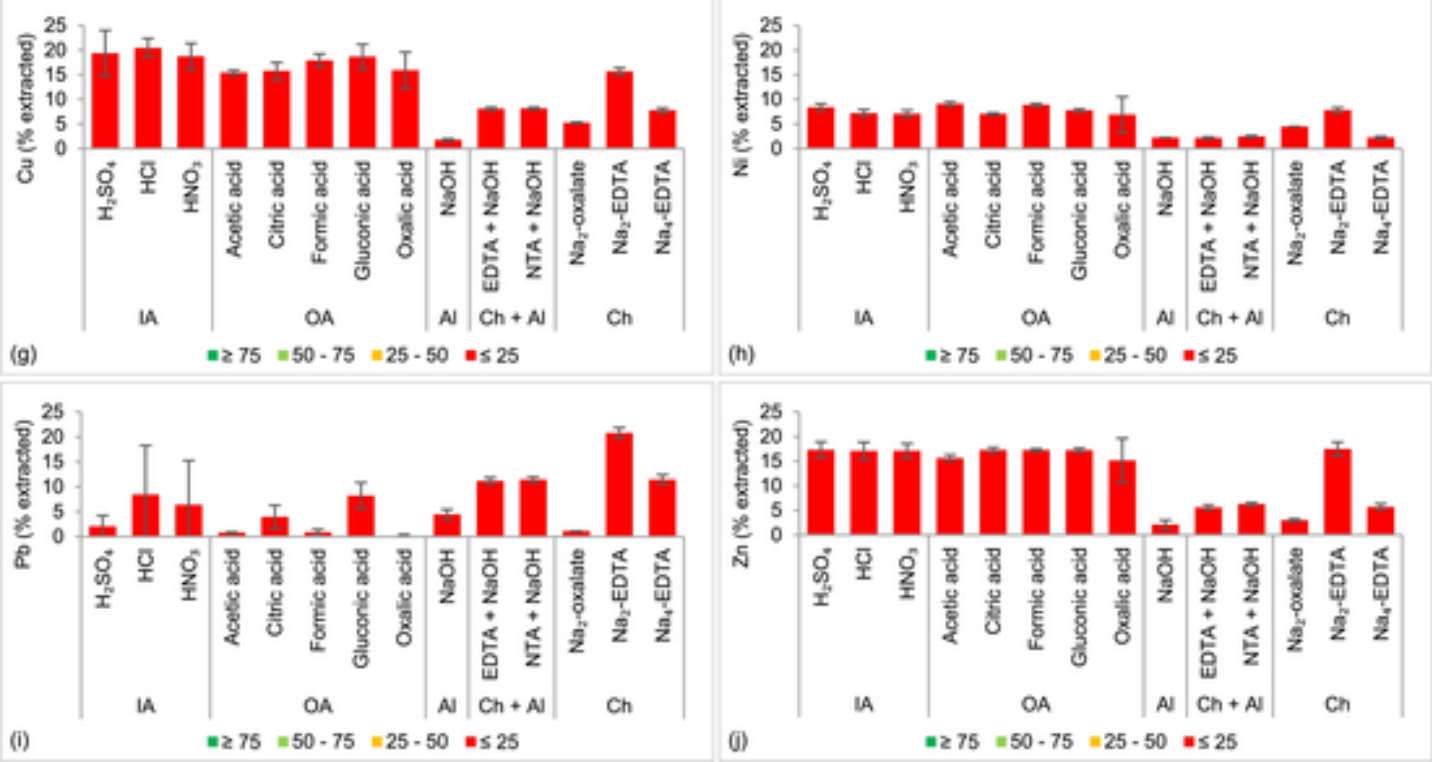

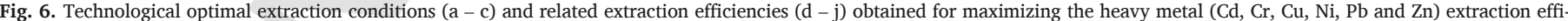

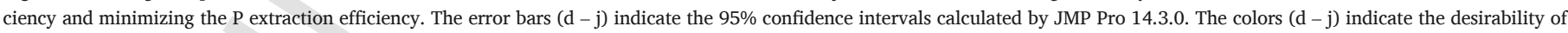

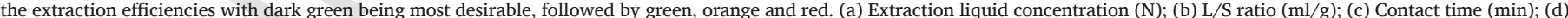

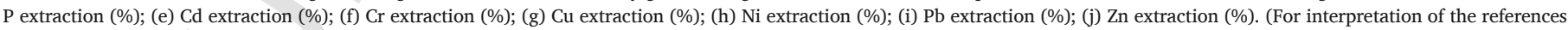
to color in this figure legend, the reader is referred to the web version of this article.)

\section{Suggestions for future research}

The scope of this study was limited to the wet $\mathrm{P}$ extraction from WWT sludge ash. Further process steps that need to be optimized are the heavy metal removal from the $\mathrm{P}$ extract and the final precipitation of $\mathrm{P}$ as, for example, struvite or Ca-phosphate. Furthermore, suitable applications have to be found for all residues of the $\mathrm{P}$ recovery process (e.g., the solid residue remaining after $\mathrm{P}$ extraction, the solid residue from heavy metals removal, the extraction liquid remaining after precipitation of the final $\mathrm{P}$ product, etc.). In this regard, the work by Liang et al. (2019), who compared $\mathrm{H}_{2} \mathrm{SO}_{4}$ and oxalic acid extraction with subsequent purification and precipitation for $\mathrm{P}$ recovery from 
WWT sludge ash, can be an interesting benchmark. Another suggestion for future research is to investigate the effect of extraction temperature on the P (and heavy metal) extraction efficiency. It would also be interesting to study the effect of the ash composition, more specifically of the $\mathrm{Al} / \mathrm{Ca}$-ratio, on the $\mathrm{P}$ extraction efficiency, as this is an important variable for controlling P extraction in conventional processes (Liang et al., 2019).

Finally, to complete the results of this study, an extended Life Cycle Analysis (LCA) and Techno-Economic Assessment (TEA) should be performed to determine which $\mathrm{P}$ fertilizer production process (i.e., production of extraction liquid, $\mathrm{P}$ extraction efficiency, purification of $\mathrm{P}$ extract, reuse of residues, etc.) offers the best combination of environmental impact and process costs. The LCA and TEA should mainly focus on the comparison of the use of $\mathrm{H}_{2} \mathrm{SO}_{4}$ and oxalic acid as extraction liquid in the $\mathrm{P}$ recovery and fertilizer production process. Additionally, a comparison with conventional $\mathrm{P}$ fertilizer production from phosphate rock could be of added value. Here, the work of Liang et al. (2019) can provide useful input.

\section{Conclusions}

Chemical characterization of the WWT sludge ash considered in this work indicated that it could not be applied as a fertilizer in Flanders because the $\mathrm{Cd}$ and $\mathrm{Zn}$ concentration exceeded the legal limit values. Hence, in order to valorize the valuable $\mathrm{P}$ in the sludge ash as a fertilizer and in this way closing the P cycle, it had to be separated from the heavy metals. XRD and SEM-EDX analysis showed that P in the sludge ash mainly occurs as whitlockite and Al-phosphates. Based on the P extraction efficiency with a $\mathrm{NaOH}$ solution, it was estimated that around $40 \%$ of total $\mathrm{P}$ was bound as Al-phosphates, whereas the other $60 \%$ was probably bound as Ca-phosphates.

DOE results indicated that $\mathrm{P}$ extraction efficiencies $>85 \%$ were only obtained with $\mathrm{H}_{2} \mathrm{SO}_{4}, \mathrm{HCl}, \mathrm{HNO}_{3}$ and oxalic acid, whereas all other extraction liquids resulted in $\mathrm{P}$ extraction efficiencies $<50 \%$. Extraction liquid concentration, $\mathrm{L} / \mathrm{S}$ ratio and contact time all affected $\mathrm{P}$ and heavy metal extraction efficiency, both individually and through interaction. In addition, type of extraction liquid and $\mathrm{pH}$ at the end of the extraction procedure also affected $\mathrm{P}$ and heavy metal extraction efficiency. More specifically, a P extraction efficiency $>85 \%$ could only be obtained at a $\mathrm{pH}<2$. This was mainly due to the fact that at a $\mathrm{pH}<2$ both Caand Al-phosphates in the ash dissolve well. The link between low $\mathrm{pH}$ and high $\mathrm{P}$ extraction efficiency was also confirmed by comparing the $\mathrm{P}$ extraction efficiencies obtained with oxalic acid and $\mathrm{Na}_{2}$-oxalate.

The multi-criteria techno-economic optimization indicated that the best trade-off between high $\mathrm{P}$ extraction, low heavy metal $(\mathrm{Cd}, \mathrm{Cr}, \mathrm{Cu}$, $\mathrm{Ni}, \mathrm{Pb}$ and $\mathrm{Zn}$ ) co-extraction and low operational costs was obtained with $\mathrm{H}_{2} \mathrm{SO}_{4}(0.5 \mathrm{~N}, 10 \mathrm{ml} / \mathrm{g}, 120 \mathrm{~min})$ and oxalic acid $(0.5 \mathrm{~N}, 12.8 \mathrm{ml}$ / $\mathrm{g}, 120 \mathrm{~min}$ ). On the one hand, $\mathrm{H}_{2} \mathrm{SO}_{4}$ outperformed the other extraction liquids in terms of extraction liquid costs per $\mathrm{kg} P$ extracted. On the other hand, extraction with oxalic acid resulted in the lowest heavy metal co-extraction, thus reducing the downstream processing costs. None of the extraction liquids considered was appropriate to use for pre-treatment since the limited removal of the heavy metals did not outweigh the considerable amount of $\mathrm{P}$ that was lost.

\section{Acknowledgements}

Funding: This work was supported by Fonds Wetenschappelijk Onderzoek Vlaanderen (FWO) (Belgium) [project number 1S08418N].

We want to thank Aquafin for supplying the WWT sludge ash sample. Furthermore, we want to thank Antoinette Deschuytere for her input on the explanation of the experimental data by means of $\mathrm{K}_{\mathrm{sp}}$ 's and chemical equilibriums.

\section{Declaration of competing interest}

The authors declare that they have no known competing financial interests or personal relationships that could have appeared to influence the work reported in this paper.

\section{Appendix A. Supplementary Material}

Supplementary Material to this article can be found online at https: //doi.org/10.1016/j.scitotenv.2019.135543.

\section{References}

Adam, C., Peplinski, B., Michaelis, M., Kley, G., Simon, F.-G., 2009. Thermochemical treatment of sewage sludge ashes for phosphorus recovery. Waste Manag. 29, 1122-1128. doi:10.1016/j.wasman.2008.09.011.

Ali, T.U., Kim, D.-J., 2016. Phosphorus extraction and sludge dissolution by acid and alkali treatments of polyaluminum chloride (PAC) treated wastewater sludge. Bioresour. Technol. 217, 233-238. doi:10.1016/j.biortech.2016.02.017.

Atienza-Martínez, M., Gea, G., Arauzo, J., Kersten, S.R.A., Kootstra, A.M.J., 2014. Phosphorus recovery from sewage sludge char ash. Biomass Bioenergy 65, 42-50. doi:10.1016/j.biombioe.2014.03.058.

Billen, P., Costa, J., Van der Aa, L., Van Caneghem, J., Vandecasteele, C., 2015. Electricity from poultry manure: a cleaner alternative to direct land application. J. Clean. Prod. 96, 467-475. doi:10.1016/j.jclepro.2014.04.016.

Biswas, B.K., Inoue, K., Harada, H., Ohto, K., Kawakita, H., 2009. Leaching of phosphorus from incinerated sewage sludge ash by means of acid extraction followed by adsorption on orange waste gel. J. Environ. Sci. 21, 1753-1760. doi:10.1016/ S1001-0742(08)62484-5.

Broos, K., Dierckx, P., Quaghebeur, M., Debaene, L., Vanaken, N., n.d. Afleiding en onderbouwing ontwerpnormen voor gebruik grondstoffen als bodemverbeterend mid$\mathrm{del} / \mathrm{meststof}$ in Vlaanderen. OVAM, Mechelen.

Chembid, n.d. Selected Supplier: Sjijiazhuang Xinlongwei Chemical co., Ltd. [WWW Document]. URL https://www.chembid.com (accessed 5.9.19).

Christensen, R., 2016. Chapter 8: Testing Lack of Fit, in: Analysis of Variance, Design, and Regression: Linear Modeling for Unbalanced Data. Chapman and Hall/CRC, New York, pp. 181-201. doi:10.1201/9781315370095.

Cohen, Y., 2009. Phosphorus dissolution from ash of incinerated sewage sludge and animal carcasses using sulphuric acid. Environ. Technol. 30, 1215-1226. doi:10.1080/ 09593330903213879.

Darwish, M., Aris, A., Puteh, M.H., Jusoh, M.N.H., Kadir, A.A., 2017. Waste bones ash as an alternative source of $P$ for struvite precipitation. J. Environ. Manag. 203, 861-866. doi:10.1016/j.jenvman.2016.02.033.

Desmidt, E., Ghyselbrecht, K., Zhang, Y., Pinoy, L., Van der Bruggen, B., Verstraete, W., Rabaey, K., Meesschaert, B., 2015. Global phosphorus scarcity and full-scale P-recovery techniques: a review. Crit. Rev. Environ. Sci. Technol. 45, 336-384. doi:10.1080/ 10643389.2013.866531.

Donatello, S., Freeman-Pask, A., Tyrer, M., Cheeseman, C.R., 2010. Effect of milling and acid washing on the pozzolanic activity of incinerator sewage sludge ash. Cem. Concr. Compos. 32, 54-61. doi:10.1016/j.cemconcomp.2009.09.002.

Donatello, S., Tong, D., Cheeseman, C.R., 2010. Production of technical grade phosphoric acid from incinerator sewage sludge ash (ISSA). Waste Manag. 30, 1634-1642. doi:10.1016/j.wasman.2010.04.009.

Ebbers, B., Ottosen, L.M., Jensen, P.E., 2015. Comparison of two different electrodialytic cells for separation of phosphorus and heavy metals from sewage sludge ash. Chemosphere 125, 122-129. doi:10.1016/j.chemosphere.2014.12.013.

European Commission, 2017. Communication from the Commission to the European Parliament, the Council, the European Economic and Social Committee and the Committee of the Regions on the 2017 List of Critical Raw Materials for the EU.

European Commission, 2019. Report from the Commission to the European Parliament, the Council, the European Economic and Social Committee and the Committee of the Regions on the Implementation of the Circular Economy Action Plan.

European Committee for Standardization, 2002. EN 13656:2002 Characterization of Waste - Microwave Assisted Digestion with Hydrofluoric (HF), Nitric $\left(\mathrm{HNO}_{3}\right)$ and Hydrochloric $(\mathrm{HCl})$ Acid Mixture for Subsequent Determination of Elements.

European Sustainable Phosphorus Platform, 2019. ESPP Phosphorus Fact Sheet. Eurostat Sewage sludge production and disposal[WWW Document]. URLhttps://ec. europa.eu/eurostat/web/products-datasets/product?code $=$ env_ww_spd2019(accessed 4.25.19)

Fang, L., Li, J., Donatello, S., Cheeseman, C.R., Wang, Q., Poon, C.S., Tsang, D.C.W., 2018. Recovery of phosphorus from incinerated sewage sludge ash by combined two-step extraction and selective precipitation. Chem. Eng. J. 348, 74-83. doi:10.1016/ j.cej.2018.04.201.

Fang, L., Li, J., Guo, M.Z., Cheeseman, C.R., Tsang, D.C.W., Donatello, S., Poon, C.S., 2018 Phosphorus recovery and leaching of trace elements from incinerated sewage sludge ash (ISSA). Chemosphere 193, 278-287. doi:10.1016/j.chemosphere.2017.11.023.

Ferreira, C., Jensen, P.E., Ottosen, L.M., Ribeiro, A.B., 2005. Removal of selected heavy metals from MSW fly ash by the electrodialytic process. Eng. Geol. 77, 339-347. doi:10.1016/j.enggeo.2004.07.024.

Franz, M., 2008. Phosphate fertilizer from sewage sludge ash (SSA). Waste Manag. 28, 1809-1818. doi:10.1016/j.wasman.2007.08.011. 
Goos, P., Jones, B., 2011. Optimal Design of Experiments: A Case Study Approach. Wiley. doi:10.1002/9781119974017.

Gorazda, K., Tarko, B., Wzorek, Z., Nowak, A.K., Kulczycka, J., Henclik, A., 2016. Characteristic of wet method of phosphorus recovery from polish sewage sludge ash with nitric acid. Open Chem 14, 37-45. doi:10.1515/chem-2016-0006.

Guedes, P., Couto, N., Ottosen, L.M., Ribeiro, A.B., 2014. Phosphorus recovery from sewage sludge ash through an electrodialytic process. Waste Manag. 34, 886-892. doi:10.1016/j.wasman.2014.02.021

Havukainen, J., Nguyen, M.T., Hermann, L., Horttanainen, M., Mikkilä, M., Deviatkin, I., Linnanen, L., 2016. Potential of phosphorus recovery from sewage sludge and manure ash by thermochemical treatment. Waste Manag. 49, 221-229. doi:10.1016/ j.wasman.2016.01.020.

Hoxha, A., Fati, D., 2016. Method for producing phosphoric acid. Patent US 9, 255, 006 B2.

Huang, K., Inoue, K., Harada, H., Kawakita, H., Ohto, K., 2011. Leaching of heavy metals by citric acid from fly ash generated in municipal waste incineration plants. J. Mater. Cycles Waste Manag. 13, 118-126. doi:10.1007/s10163-011-0001-5.

Jadhav, U.U., Biswal, B.K., Chen, Z., Yang, E.-H., Hocheng, H., 2018. Leaching of metals from incineration bottom ash using organic acid. J. Sustain. Metall. 4, 115-125. doi:10.1007/s40831-018-0161-9.

JMP, n.d. Desirability profiling and optimization [WWW Document]. URL https:// www.jmp.com/support/help/14-2/desirability-profiling-and-optimization.shtml (accessed 4.23.19).

Johnson, E., 1931. Process of converting phosphate rock into soluble compounds and of separating its content of lime and phosphoric acid. Patent US 1,816,285 A.

Komiyama, T., Kobayashi, A., Yahagi, M., 2013. The chemical characteristics of ashes from cattle, swine and poultry manure. J. Mater. Cycles Waste Manag. 15, 106-110. doi:10.1007/s10163-012-0089-2

Kootstra, A.M.J., Brilman, D.W.F., Kersten, S.R.A., 2019. Dissolution of phosphate from pig manure ash using organic and mineral acids. Waste Manag. 88, 141-146. doi:10.1016/j.wasman.2019.03.038.

Li, J., Xue, Q., Fang, L., Poon, C.S., 2017. Characteristics and metal leachability of incinerated sewage sludge ash and air pollution control residues from Hong Kong evaluated by different methods. Waste Manag. 64, 161-170. doi:10.1016/ j.wasman.2017.03.033

Li, J., Chen, Z., Wang, Q., Fang, L., Xue, Q., Cheeseman, C.R., Donatello, S., Liu, L., Poon, C.S., 2018. Change in re-use value of incinerated sewage sludge ash due to chemical extraction of phosphorus. Waste Manag. 74, 404-412. doi:10.1016/ j.wasman.2018.01.007.

Liang, S., Chen, H., Zeng, X., Li, Z., Yu, W., Xiao, K., Hu, J., Hou, H., Liu, B., Tao, S., Yang, J., 2019. A comparison between sulfuric acid and oxalic acid leaching with subsequent purification and precipitation for phosphorus recovery from sewage sludge incineration ash. Water Res. 159, 242-251. doi:10.1016/j.watres.2019.05.022.

Luyckx, L., 2016. Fosforherwinning uit pluimveemestverbrandingsassen en uit beendermeel. Masterproef ingediend tot het behalen van de graad van Master of Science in de Industriële Wetenschappen: Chemie: Sustainable Process and Materials Engineering. Faculteit Industriële Ingenieurswetenschappen, Campus Groep T, KU Leuven.

Luyckx, L., de Leeuw, G.H.J., Van Caneghem, J., 2019. Characterization of poultry litter ash in view of its valorization. Waste and Biomass Valorization doi:10.1007/ s12649-019-00750-6.

Mattenberger, H., Fraissler, G., Brunner, T., Herk, P., Hermann, L., Obernberger, I., 2008 Sewage sludge ash to phosphorus fertiliser: variables influencing heavy metal removal during thermochemical treatment. Waste Manag. 28, 2709-2722. doi:10.1016/ j.wasman.2008.01.005. Obermiller, D.J., n.d. Multiple response optimization using JMP.

Pettersson, A., Amand, L.-E., Steenari, B.-M., 2008. Leaching of ashes from co-combustion of sewage sludge and wood - part I: recovery of phosphorus. Biomass Bioenergy 32, 224-235. doi:10.1016/j.biombioe.2007.09.016.

Petzet, S., Peplinski, B., Cornel, P., 2012. On wet chemical phosphorus recovery from sewage sludge ash by acidic or alkaline leaching and an optimized combination of both. Water Res. 46, 3769-3780. doi:10.1016/j.watres.2012.03.068.

Stemann, J., Peplinski, B., Adam, C., 2015. Thermochemical treatment of sewage sludge ash with sodium salt additives for phosphorus fertilizer production - analysis of underlying chemical reactions. Waste Manag. 45, 385-390. doi:10.1016/ j.wasman.2015.07.029.

Takahashi, M., Kato, S., Shima, H., Sarai, E., Ichioka, T., Hatyakawa, S., Miyajiri, H., 2001. Technology for recovering phosphorus from incinerated wastewater treatment sludge. Chemosphere 44, 23-29. doi:10.1016/S0045-6535(00)00380-5.

Takhim, M., 2013. Process for the production of high purity phosphoric acid. Patent US $8,425,872$ B2.

Takhim, M., 2016. Method for recovering ash from waste incineration. Patent US 2016/0312333 A1.

Telford, J.K., 2007. A brief introduction to design of experiments. Johns Hopkins APL Tech. Dig. 27, 224-232.

The Water Research Foundation, 2019. Webcast: Phosphorus Recovery and Management.

U.S. Geological Survey, 2019. Mineral Commodity Summaries 2019: Phosphate Rock. doi:10.3133/70202434.

Umans, L., Werquin, W., 2006. Inventaris van de Vlaamse afvalverbrandingssector. OVAM, Mechelen.

E. Vitz J.W. Moore J. Shorb X. Prat-Resina T. Wenderorff A. Hahn Solubility of salts of week acids: calcium salts [WWW Document]URLhttps://chem.libretexts. org/Ancillary_Materials/Exemplars_and_Case_Studies/Exemplars/Foods/Solubility_of Salts_of_Weak_Acids\%3A_Calcium_Salts2019

VLAREMA annex 2.3.1.A [WWW Document] Besluit van de Vlaamse Regering to vaststelling van het Vlaams reglement betreffende het duurzaam beheer van materi- aalkringlopen en afvalstoffenURLhttps://navigator.emis.vito.be/mijnnavigator? woId $=439912018$

Wang, Q., Li, J., Tang, P., Fang, L., Poon, C.S., 2018. Sustainable reclamation of phosphorus from incinerated sewage sludge ash as value-added struvite by chemical extraction, purification and crystallization. J. Clean. Prod. 181, 717-725. doi:10.1016/ j.jclepro.2018.01.254.

Xu, H., He, P., Gu, W., Wang, G., Shao, L., 2012. Recovery of phosphorus as struvite from sewage sludge ash. J. Environ. Sci. 24, 1533-1538. doi:10.1016/ S1001-0742(11)60969-8.

Zhang, Y., Cetin, B., Likos, W.J., Edil, T.B., 2016. Impacts of pH on leaching potential of elements from MSW incineration fly ash. Fuel 184, 815-825. doi:10.1016/ j.fuel.2016.07.089. 